\title{
GROUNDWATER RESOURCES OF NANKA SANDS AQUIFERS AROUND NANKA-OKO AREA, SOUTHEASTERN NIGERIA
}

\section{O. V. OMONONA, B. C. OZOBIALU AND C. O. OKOGBUE}

(Received 15 November 2016; Revision Accepted 2 February 2017)

\begin{abstract}
Investigations were carried out for groundwater potentials and hydro-geochemical characteristics of the Nanka-Oko area, southeastern, Nigeria. The area is underlain by the Nanka Sands Formation. Data from 14 vertical electrical soundings (VES) were interpreted using IPI2win software. A total of 16 groundwater samples, were also analyzed for their physiochemical and biological properties with the aim of assessing their characteristics and quality for domestic and agricultural purposes. Based on the computed aquifer parameter (transmissivity), two groundwater potentials zones (very high and high) were defined. Only $\mathrm{SO}_{4}^{2-}$ among the major ions shows a pronounced difference in concentrations from the two aquifer horizon types. The geochemical data also reveal that the groundwater from the area is not generally suitable for domestic but adequate for irrigation purposes.
\end{abstract}

KEYWORDS: Aquifer type; groundwater potentials; hydrochemical characteristics; Nanka Sands

\section{INTRODUCTION}

Demand for groundwater for domestic, agricultural and industrial uses has increased globally because of its attendant advantages over other sources of water. According to Vasanthavigar et al (2010) groundwater exists almost everywhere as subsurface resource not in a single widespread aquifer but in several thousand local aquifer systems and compartments that have similar characters. In basement complex terrains, aquifers occur locally and in discontinuous units while in most sedimentary environments, they occur on regional scales and in continuous units. The quantity and quality of groundwater of an aquifer depend on a number of factors which among others include lithology, geologic structures, atmospheric precipitation, pattern and rate of recharge, inland surface water and subsurface geochemical processes. These factors indeed determine the groundwater potentials of an area and to some extent the hydrochemical characteristics of the aquifers. Numerous studies have been done in Nigeria and other parts of the world on the evaluation of groundwater potentials and hydrochemical characteristics of aquifers. Some of these studies in Nigeria include those of Abiolaet al. (2009), Atakpo and Ayolabi (2009), Ehirim and Ofor (2011), Oyedeleet al. (2011), Okogbue et al. 2012, Adenijiet al (2013), Okogbue and Omonona (2013), Okogbue and Ukpai (2013), Omonona et al (2013), Onwuka et al (2013). Those done outside Nigeria include Woodruff et al. (1972), Flores-Marques et al. (2001), Braga et al. (2006), Mondalet al (2010). Of all the studies done in Nigeria only few (Egboka and Okpoko, 1984, Uma et al., 1989, and Okoro et al, 2010) are in the Nanka area of southeastern Nigeria where groundwater constitutes the dominant source of water supply and is accessed via shallow hand dug wells as well as deep boreholes.

These boreholes and hand dug wells often fail or yield poorly especially during the dry season and sometimes permanently due to poor siting in terms of production capacity of well location. Increased urbanization of Nanka with a population growth rate of $2.83 \%$ (Census, 1991) and adjoining towns with attendant increase in demand for potable water for domestic and agricultural purposes has increased interest in groundwater studies of the area. With the presence of Federal Polytechnic at Oko, College of Pharmacy at Agulu, and a perennial expanding Ekwuluobia Market for example, more groundwater exploration has become necessary. The objectives of this study were to determine and characterize the groundwater potentials of the area using the aquifer parameters as well as the hydrochemical characteristics.

\section{DESCRIPTION OF THE STUDY AREA}

The study area (Nanka-Oko area) lies between latitudes $6^{\circ} 00$ and $6^{\circ} 08^{\prime}$ North, and longitude $7^{\circ} 00^{\prime}$ and $7^{0} 08^{\prime}$ East with a total area of $12.67 \mathrm{~km}^{2}$ (Figures 1 ). The climate of the area is tropical with an average yearly rainfall of $1478 \mathrm{~mm}$, daily minimum and maximum temperatures of $22^{\circ}$ and $33^{\circ} \mathrm{C}$, respectively. Relative humidity ranges from $60 \%$ (at dry seasons) to $90 \%$ (at rainy seasons) (Izuchukwu, 2010). Two seasons exist namely, wet season (March to October) and dry season (November to February). The dry season is characterized by dry air mass, causing high evapotranspiration rate and lowering of water levels while the

O. V. Omonona, Department of Physic/Geology/Geophysics, Federal University, Ndufu Alike, Ikwo, Nigeria.

B. C. Ozobialu, Department of Geology, University of Nigeria, Nsukka, Nigeria.

C. O. Okogbue, Department of Geology, University of Nigeria, Nsukka, Nigeria. 
rainy season is a period of heavy downpours, ground infiltration and elevation of ground water table (Egboka and Okpoko, 1984). Undulating landforms characterize the topography of the area. The undulation is caused by serious gullying that is less intense towards the southeastern parts of the area (Izuchukwu, 2010).

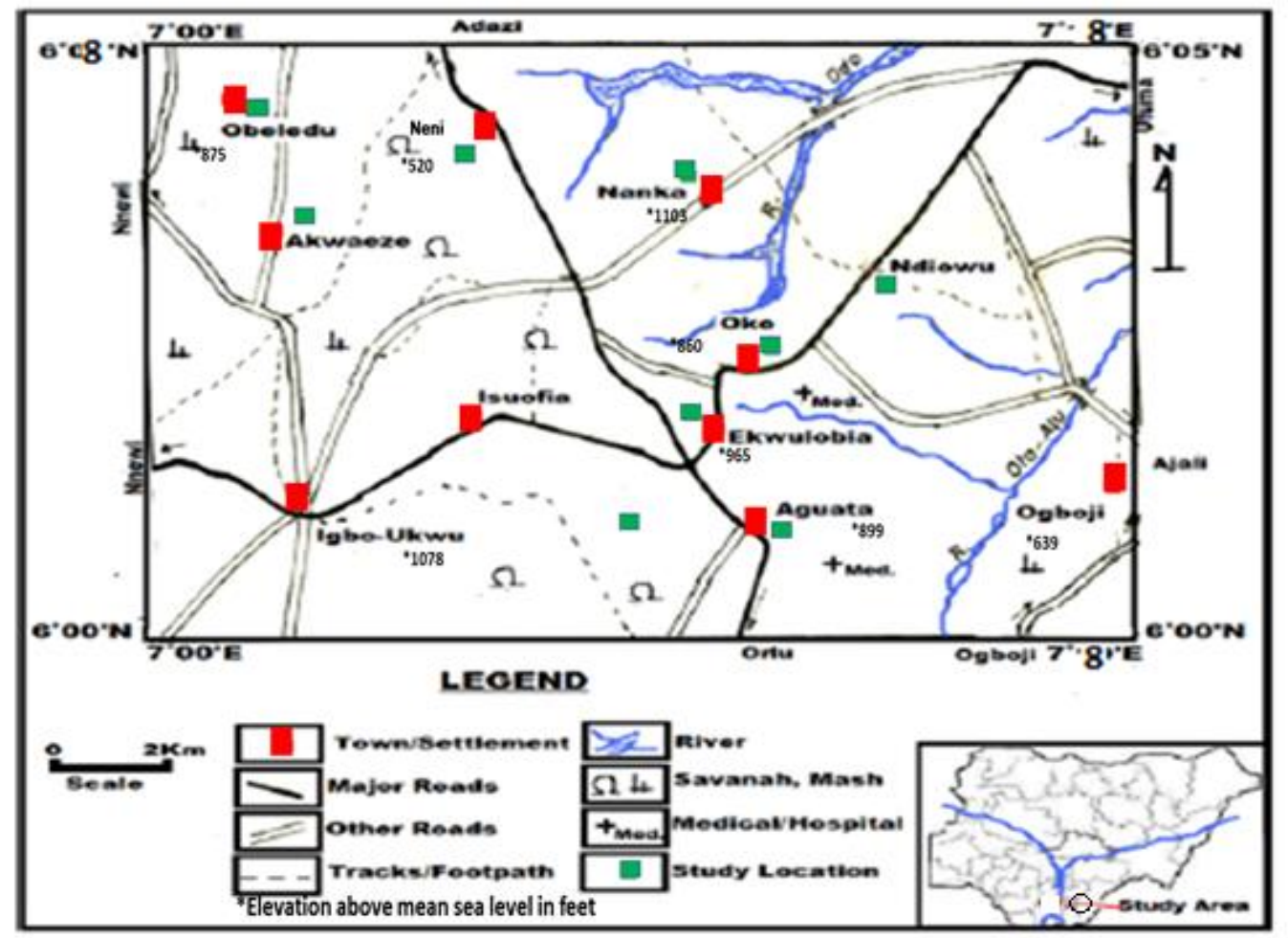

Figure 1: Location map of the study area (Adapted from Okengwo et al, 2015).

\section{GEOLOGY AND HYDROGEOLOGY}

The study area is part of the Anambra River Basin of southern Nigeria. The dominant geological Formation is the Eocene Nanka Sands (Figure 2) which is a sequence of unconsolidated or poorly consolidated sands, $305 \mathrm{~m}$ thick, underlain by the Imo Shale Formation of Paleocene age and overlain by the lignite clay seams of the Oligocene Ogwashi Asaba Formation.
The Nanka Sands are predominantly sandy with thin clay stone and siltstone bands, lenses and laminations. The sand is poorly sorted, cross bedded and medium to coarse grained. The deposits also exhibit well developed patterns of alternating cross bedded sands and layers of dark grey shales. The aquifer-aquitard units form a multi-aquifer system. The general stratigraphy of Anambra Basin is presented in Table1. 


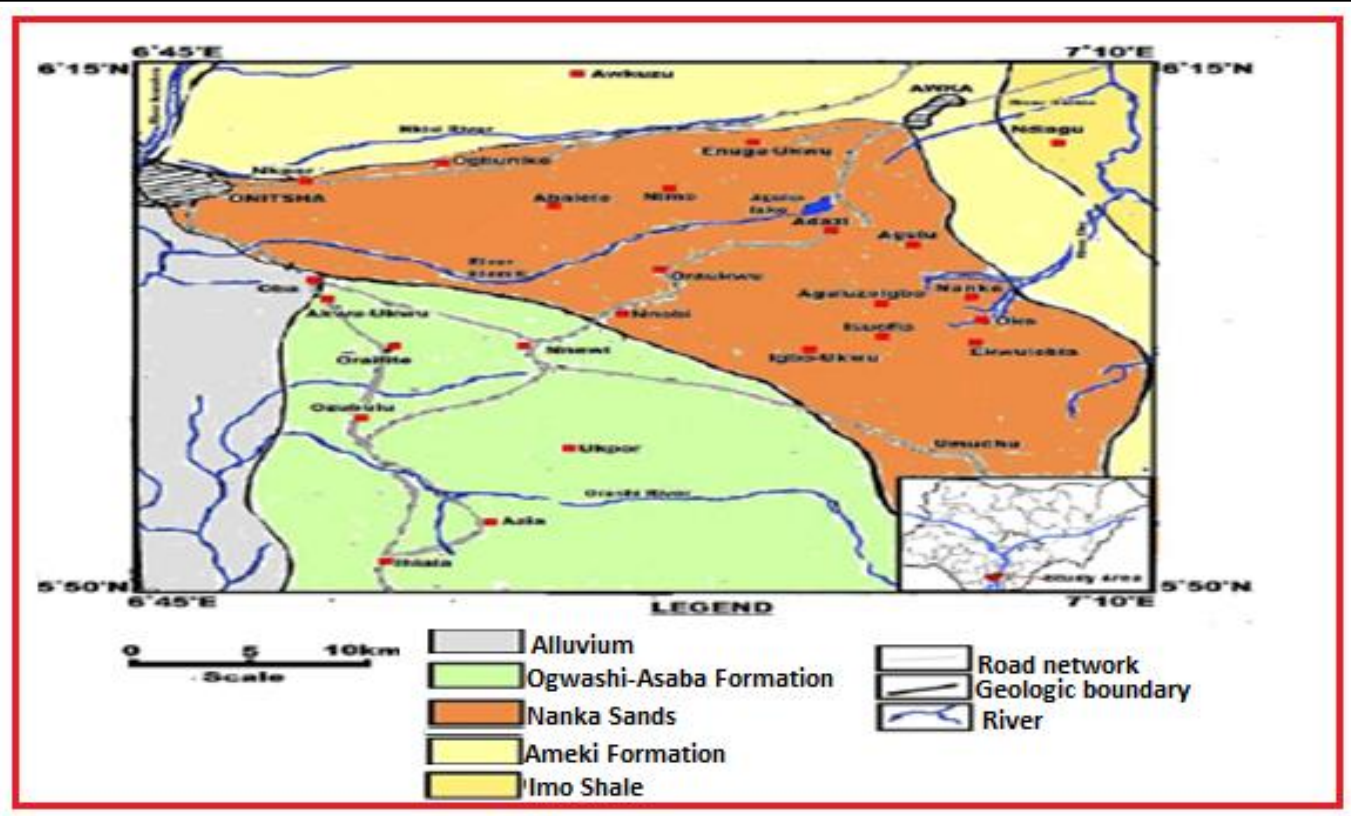

Figure 2: Geologic map of the study area (source: Okengwo et al., 2015)

Around Nanka, Idemili and Oko, the water table is generally deep to very deep ranging from $30 \mathrm{~m}$ to $300 \mathrm{~m}$ in depth (Offodile, 2002). Thus the aquifers in these areas can be tapped only by deep boreholes. Shallower water tables are obtained in boreholes located in lowland areas or valleys usually interspersing the predominantly hilly areas.

Springs issue profusely at outcrop points, where the water table is intersected by deep erosional valleys forming scenic lakes at the foot of the hill.

Table 1: Stratigraphy of Anambra Basin

\begin{tabular}{|c|c|c|c|}
\hline Age & Formation & Lithology & $\begin{array}{l}\text { Thickness } \\
(\mathrm{m})\end{array}$ \\
\hline Oligocene & Benin & Sands, lenticular shale and clay & $>1000$ \\
\hline $\begin{array}{l}\text { Miocene- } \\
\text { Oligocene }\end{array}$ & Ogwashi-Asaba & $\begin{array}{l}\text { Unconsolidated sandstone with mudstone, lignite } \\
\text { seams }\end{array}$ & 500 \\
\hline Eocene & Ameki/Nanka Sands & $\begin{array}{l}\text { Sandstone and siltstone with clays as lenses. Nanka } \\
\text { Sands consist of fine-coarse sandstone with lensesof } \\
\text { calcareous shale }\end{array}$ & 130 \\
\hline Paleocene & $\begin{array}{l}\text { Imo Shale/Ebenebe } \\
\text { Sandstone Member }\end{array}$ & $\begin{array}{l}\text { Fine tectural dark grey shale with arenaceous } \\
\text { sandstone }\end{array}$ & $400 / 10-40$ \\
\hline $\begin{array}{l}\text { Masastrichtian- } \\
\text { Paleocene }\end{array}$ & Nsukka & Dark shale, sandy-shale, carbonaceous shale & $>300$ \\
\hline Maastricchtian & Ajali Sandstone & Sandstone & $300-1000$ \\
\hline Campanian & Mamu & $\begin{array}{l}\text { Sandstone, shale mudstone, sandy-shale, coal } \\
\text { seams }\end{array}$ & $75-1000$ \\
\hline Campanian & Nkporo & Dark grey shale, fissile shale & 335.28 \\
\hline
\end{tabular}

\section{MATERIALS AND METHODS}

Vertical electrical sounding (VES) was used to determine the geo-electric layers of fourteen (14) locations spread across the study area and within the vicinity of existing borehole locations. The VES was carried out using ABEM SAS 300 Terrameter with Schlumberger electrode array and a maximum current electrodes spacing of $316 \mathrm{~m}$. The field results were interpreted using the IPI2Win software.
Although electrical sounding is the most appropriate geophysical tool for groundwater prospecting, it has limitations, the most of which is the masking of micro geologic features due to the distance of electrode spread. This limitation was taken care of by comparing the VES results with geologic log of drill cuttings from boreholes drilled by Anambra State Water Board which gives better results as it makes up for the deficiencies of electrical sounding. 
Hydraulic conductivity values from the area were estimated from grain size analysis results using empirical relationship of Uma et al. (1989):

$\mathrm{K}=6.0 d_{10}^{2}$

(for poorly consolidated sand)

where

$\mathrm{K}=$ hydraulic conductivity $(\mathrm{cm} / \mathrm{s})$

$d_{10}^{2}=$ effective grain size $\mathrm{cm}(10 \%$ particles are finer,

$90 \%$ coarser), and

The transmissivity values were determined from the calculated hydraulic conductivity values using the mathematical relation;

$\mathrm{T}=\mathrm{Kb}$

2

where

$\mathrm{T}$ is the transmissivity $\left(\mathrm{cm}^{2} / \mathrm{s}\right)$

$b$ is the aquifer thickness $(m)$.

A total of fourteen (14) groundwater samples from boreholes were collected each with a 2-litre plastic container. The water samples were first used to rinse the containers before collection of the samples to be analyzed in the laboratory. The water samples were carefully labeled accordingly, stored in cool dry boxes and then transported to the laboratory to be tested within 24 hours. The samples that could not be tested on the day of collection were stored in the refrigerator at a constant temperature of $4^{\circ} \mathrm{C}$. However, measurements of physical parameters, $\mathrm{pH}$ and temperature, were carried out in the field using WTW LF 91 model meter. EC was measured using EC meter model 3084 at the points of sample collection. The determinations of the other physiochemical parameters (minor and major elements) were conducted at the Enugu State Water Board Corporation, Enugu using standard procedures of EPA (2005).

Total dissolved solids (TDS) was determined by evaporation method involving gravimetric analysis, and this method has a detection limit of approximately $10 \mathrm{mg} / \mathrm{l} . \mathrm{Na}^{+}$and $\mathrm{K}^{+}$were determined by the flame photometric method, using Gallen Kamp Flame Analyzer (FGA 330c model). $\mathrm{Ca}^{2+}$ and $\mathrm{Mg}^{2+}$ were determined by titrimetric method using EDTA complexometric method. $\mathrm{SO}_{4}^{2-}$ and $\mathrm{NO}_{3}^{-}$were determined by turbidometric titration using a spectrophotometer (Spronic 205 model). $\mathrm{Cl}^{-}$was determined by electrometric titration of the water using a chloridometer (model 4425000). $\mathrm{HCO}_{3}{ }^{-}$concentration in water was by titration of water with dilute $(0.025 \mathrm{M}) \mathrm{H}_{2} \mathrm{SO}_{4}$ acid having a routine detection limit of $0.1 \mathrm{meq} / \mathrm{l}$. $\mathrm{PO}_{4}^{2-}$ was analyzed using HP liquid chromatography (Flexar SQ 300MS) method. Total $\mathrm{Fe}$ was determined by phenanthrolin method (Onwuka et al., 2013). Trace elements such as lead $(\mathrm{Pb})$, chromium $(\mathrm{Cr})$, cadmium $(\mathrm{Cd})$, manganese $(\mathrm{Mg})$ were determined with digital Bulk Scientific 205 Atomic Absorption Spectrophotometer (AAS).
Irrigation water quality indices were determined using the following relationships with the anions and cations measured in $\mathrm{meq} / \mathrm{l}$ in order to evaluate the suitability of the groundwater of the area for irrigation purposes (Brindha and Elango 2011; Ayuba et al, 2013). Sodium percentage $(\mathrm{Na} \%)$ :

$\mathrm{Na} \%=\frac{\mathrm{Na}+\mathrm{K}^{+}}{\mathrm{Ca}^{2+}+\mathrm{Mg}^{2+} \mathrm{Na}^{+}+\mathrm{K}^{+}} \times 100 \ldots \ldots \ldots \ldots \ldots$

Sodium adsorption ratio (SAR):

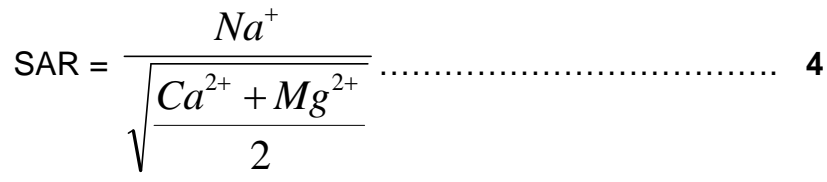

Residual sodium carbonate (RSC):

$\mathrm{RSC}=\left(\mathrm{CO}_{3}^{2-}+\mathrm{HCQ}_{3}\right)+\left(\mathrm{Ca}^{2+}+\mathrm{Mg}^{2+}\right) \ldots \ldots \ldots$

Permeability index (PI):

$\mathrm{PI}=\frac{\left(\mathrm{Na}^{+}+\left(\sqrt{\mathrm{HCO}_{3}^{-}}\right)\right.}{\left(\mathrm{Ca}^{2+}+\mathrm{Mg}^{2+}+\mathrm{Na}^{+}\right.} \times 100 \ldots \ldots \ldots \ldots \ldots \ldots \ldots \ldots \ldots \ldots \ldots$

Magnesium hazard $(\mathrm{MH})$ :

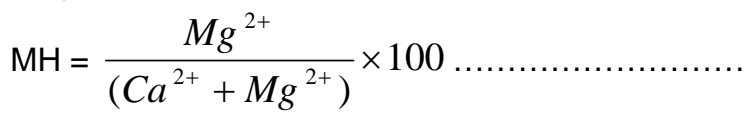

Kelly ratio $(\mathrm{KR})$ :

$\mathrm{KR}=\frac{\mathrm{Na}^{+}}{\mathrm{Ca}^{2+}+M g^{2+}} \ldots \ldots \ldots \ldots . . . . . .$.
RESULTS AND DISCUSSION

\section{Geoelectrical characterization}

The geo-electric layers with their corresponding thicknesses and resistivities are shown in Table 2. The table shows that the area is characterized by 4,5 and 6 subsurface geo-electric layers. Eight curve types were defined based on the layers' resistivity relationships namely, QHAK (4), HAAK (2), AAKQ (1), HAK (2), KQQ (1), AKQ (1), AAK (2) and AK (1). The QHAK, HAAK and $A A K Q$ denote a 6-subsurface geo-electric layers section with various layers' resistivity relationships while the HAK, KQQ, and AAK are characteristic of a 5subsurface layers section with different layers' resistivity relationships. AK is a 4-subsurface layer section. The four curve types, $\mathrm{H}=\rho_{1}>\rho_{2}<\rho_{3}, \mathrm{~A}=\rho_{1}<\rho_{2}<\rho_{3}, \mathrm{~K}=\rho_{1}<\rho_{2}>\rho_{3}$ and $Q=\rho_{1}>\rho_{2}>\rho_{3}$ of a 3-subsurface layer section form the basis for the establishments of different curve types for a 4- or more- subsurface layers sections. In general, an $n$-layer section (where $\geq 3$ ) is described by $n$-2 letters. The layers' resistivity relationships for each of the curve types mentioned above are presented in (Table 3). Uga is characterized by 4,5 and 6 subsurface geoelectric layers which reveal variability in the subsurface geology, 6 subsurface geoelectric layers was also observed at Akwaeze. The other locations show 5 geolectric 
Table 2: Summary of the results of resistivity and layer thicknesses from surveys

\begin{tabular}{|c|c|c|c|c|c|c|c|c|}
\hline Location & $\begin{array}{l}\text { Ist } \\
\text { layer }\end{array}$ & $\begin{array}{l}2^{\text {nd }} \\
\text { layer }\end{array}$ & $\begin{array}{l}3^{\text {rd }} \\
\text { layer }\end{array}$ & $\begin{array}{l}4^{\text {th }} \\
\text { layer }\end{array}$ & $\begin{array}{l}5^{\text {th }} \\
\text { layer }\end{array}$ & $6^{\text {th }}$ layer & $\begin{array}{l}\text { Longitudinal } \\
\text { Conductance }\end{array}$ & $\begin{array}{l}\text { Curve } \\
\text { type }\end{array}$ \\
\hline Uga 2 & $\begin{array}{l}4.42 \\
2098.5\end{array}$ & $\begin{array}{l}6.43 \\
1299\end{array}$ & $\begin{array}{l}14.4 \\
556\end{array}$ & $\begin{array}{l}21.9 \\
6058\end{array}$ & $\begin{array}{l}78.1 \\
3677\end{array}$ & $-\overline{6363}$ & 0.057811 & QHAK \\
\hline Uga 1 & $\begin{array}{l}2.82 \\
184\end{array}$ & $\begin{array}{l}8.54 \\
6263\end{array}$ & $\begin{array}{l}39.4 \\
325\end{array}$ & $\begin{array}{l}- \\
1489\end{array}$ & & & 0.13792 & AK \\
\hline Uga 3 & $\begin{array}{l}1.72 \\
3109.5\end{array}$ & $\begin{array}{l}4.01 \\
1573\end{array}$ & $\begin{array}{l}18.1 \\
4622\end{array}$ & $\begin{array}{l}63.6 \\
1483\end{array}$ & $\begin{array}{l}- \\
10804\end{array}$ & & 0.049905 & HAK \\
\hline Mkpologwu & $\begin{array}{l}1.793 \\
166.5\end{array}$ & $\begin{array}{l}8.37 \\
4692\end{array}$ & $\begin{array}{l}35.6 \\
2420\end{array}$ & $\begin{array}{l}92 \\
621\end{array}$ & $\begin{array}{l}- \\
1937\end{array}$ & & 0.175412 & $K Q Q$ \\
\hline Ekwulobia & $\begin{array}{l}3.3 \\
469\end{array}$ & $\begin{array}{l}9.45 \\
2744\end{array}$ & $\begin{array}{l}21.6 \\
9287\end{array}$ & $\begin{array}{l}102 \\
4263\end{array}$ & -6374 & & 0.036733 & $A K Q$ \\
\hline Oko 1 & $\begin{array}{l}1.9 \\
2255\end{array}$ & $\begin{array}{l}7.62 \\
753\end{array}$ & $\begin{array}{l}21.1 \\
5096\end{array}$ & $\begin{array}{l}62.4 \\
4559\end{array}$ & -8 & & 0.02879 & HAK \\
\hline Oko 2 & $\begin{array}{l}1.39 \\
256\end{array}$ & $\begin{array}{l}13.65 \\
987\end{array}$ & $\begin{array}{l}23 \\
2219\end{array}$ & $\begin{array}{l}75.7 \\
161\end{array}$ & $\begin{array}{l}- \\
8312\end{array}$ & & 0.499811 & AAK \\
\hline $\begin{array}{l}\text { Adazi } \\
\text { Nnukwu }\end{array}$ & $\begin{array}{l}0.816 \\
53\end{array}$ & $\begin{array}{l}5.99 \\
184\end{array}$ & $\begin{array}{l}28.3 \\
2877\end{array}$ & $\begin{array}{l}58.99 \\
303\end{array}$ & - & & 0.252474 & AAK \\
\hline Akwaeze & $\begin{array}{l}1.33 \\
2216\end{array}$ & $\begin{array}{l}5.31 \\
1586\end{array}$ & $\begin{array}{l}10.3 \\
4567\end{array}$ & $\begin{array}{l}40 \\
8551\end{array}$ & $\begin{array}{l}49.1 \\
7445\end{array}$ & $\begin{array}{l}- \\
12185\end{array}$ & 0.017476 & HAAK \\
\hline Neni 2 & $\begin{array}{l}2.9 \\
5370\end{array}$ & $\begin{array}{l}4.29 \\
1989\end{array}$ & $\begin{array}{l}7.36 \\
10001\end{array}$ & $\begin{array}{l}81.9 \\
4446\end{array}$ & $\begin{array}{l}- \\
13925\end{array}$ & & 0.021854 & QHAK \\
\hline Obeledu 1 & $\begin{array}{l}1.6 \\
2672\end{array}$ & $\begin{array}{l}7.14 \\
246\end{array}$ & $\begin{array}{l}14 \\
544\end{array}$ & $\begin{array}{l}72.5 \\
5179\end{array}$ & $\begin{array}{l}- \\
1852\end{array}$ & & 0.069357 & QHAK \\
\hline Obeledu 2 & $\begin{array}{l}14.54 \\
1249\end{array}$ & $\begin{array}{l}26.6 \\
3705\end{array}$ & $\begin{array}{l}51.1 \\
11562\end{array}$ & $\begin{array}{l}81.3 \\
3157\end{array}$ & 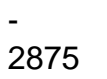 & & 0.048993 & AAKQ \\
\hline Agulu & $\begin{array}{l}2.43 \\
827\end{array}$ & $\begin{array}{l}13.2 \\
171\end{array}$ & $\begin{array}{l}19.8 \\
1003\end{array}$ & $\begin{array}{l}64.7 \\
2886\end{array}$ & $\begin{array}{l}- \\
9474\end{array}$ & & 0.122291 & QHAK \\
\hline Nanka & $\begin{array}{l}1.96 \\
143\end{array}$ & $\begin{array}{l}8.97 \\
133\end{array}$ & $\begin{array}{l}6.81 \\
268\end{array}$ & $\begin{array}{l}68.7 \\
1644\end{array}$ & - & & 0.148349 & HAAK \\
\hline
\end{tabular}

the upper values represent the layer thickness $(\mathrm{m})$ and the lower values the resistivity $\mathrm{m}$

Table 3: Classification of curve types

\begin{tabular}{|c|c|}
\hline Curve type & Layer's resistivity relationship \\
\hline $\mathrm{QHAK}$ & mavira \\
\hline HAAK & 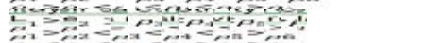 \\
\hline AAKQ & 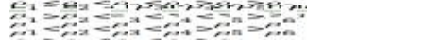 \\
\hline HAK & 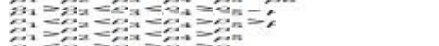 \\
\hline$K Q Q$ & 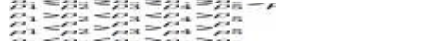 \\
\hline $\mathrm{AKQ}$ & 20 \\
\hline AAK & 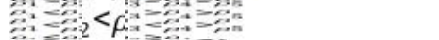 \\
\hline AK & 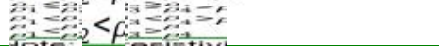 \\
\hline
\end{tabular}

layers. The VES curves are presented in figures $3 a$ to 31. In order to ascertain the correctness of the VES results, some of the geoelectric sections (Ekwulobia, Akweze and Neni,) were correlated with lithologic logs obtained from those localities, (Figure 4). From the figures, the geoelectric sections from Ekwulobia, Akweze and Neni showed similar number of layers with the lithologic logs from the same area.

\section{Aquifers characteristics and parameters}

The Nanka Sands generally dips southwest in the Anambra Basin. The geology as revealed by the logs is characterized with upper reddish to brown ferruginised sands underlain by coarse to fine grained sands alternating with lenses of siltstones, silty shale and a predominant shale member interbedded with sands and sandstone horizons. Two aquifer horizons, upper and lower horizons were identified based on the lithologic logs, geoelectric sections and static water levels measured in the area. These aquifer horizons are well seen in Figure 5 where for example, the Ekwulobia, Akweze, and Ugageolectric sections show lower $(>50$ $\mathrm{m})$ aquifer horizons whereas the Neni sections show upper $(<50 \mathrm{~m})$ aquifer horizons. The upper horizon aquifer was also observed at Oko, Agulu, Nanka and Mkpologwu areas while the lower horizon aquifer was also observed at Obeledu. All the upper horizon aquifers are found within 


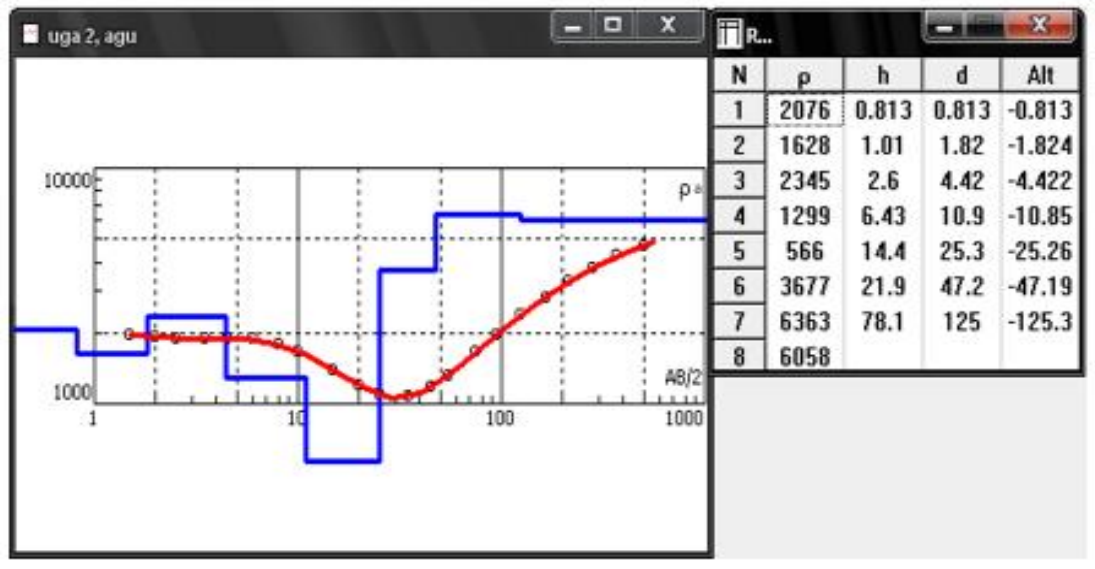

Figure 3a: Vertical electrical sounding (VES) curves for Uga 2

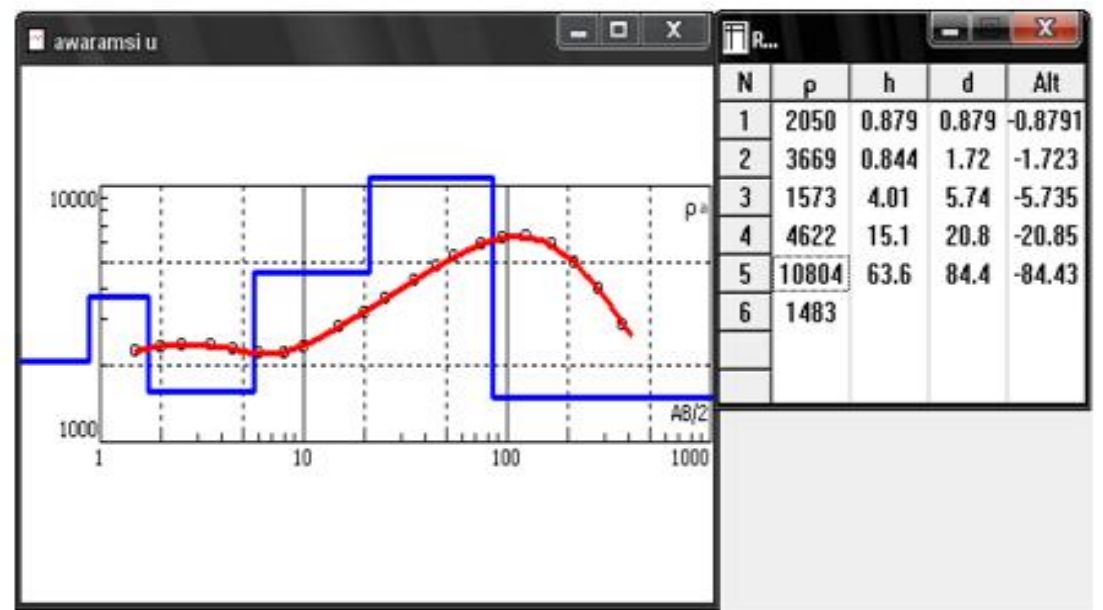

Figure 3b: Vertical electrical sounding (VES) curves for Awaramsiu

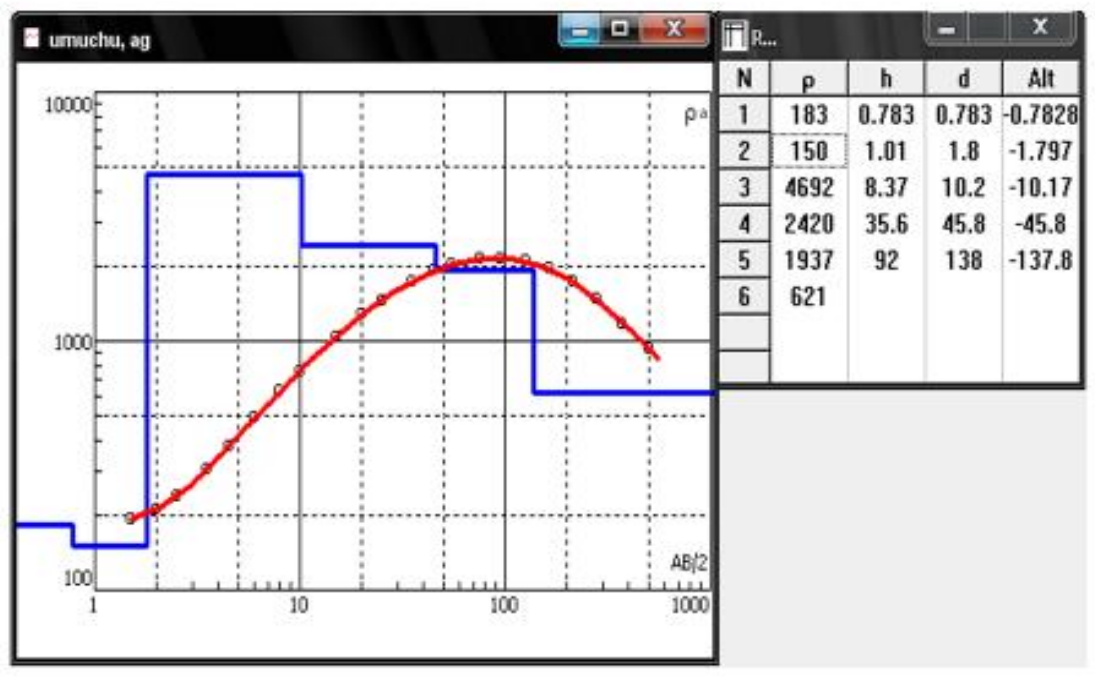

Figure 3c: Vertical electrical sounding (VES) curves for Umuchu 


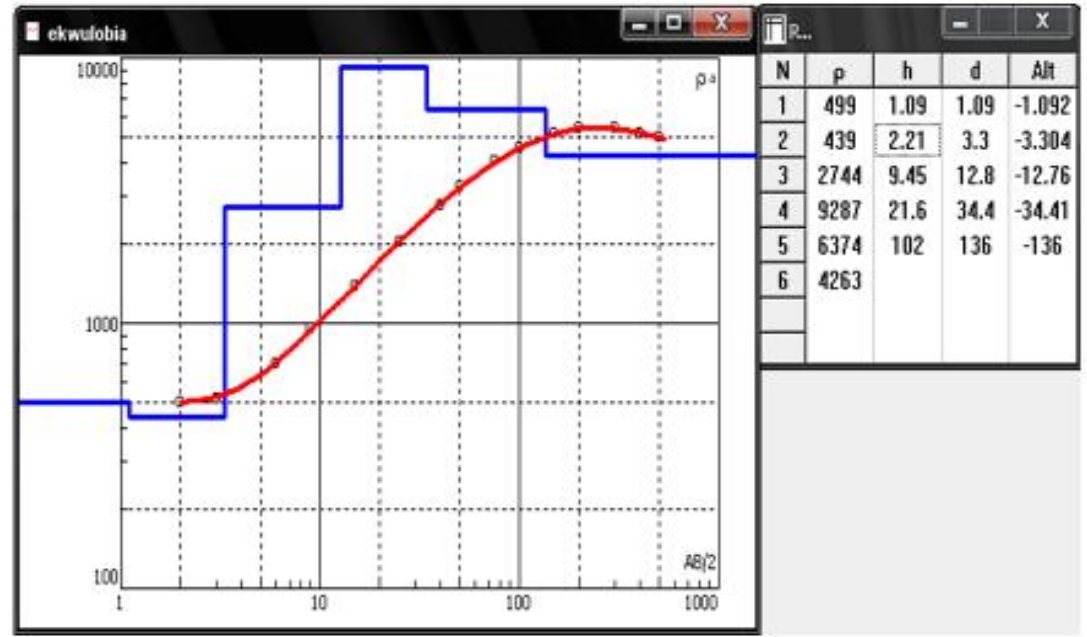

Figure 3d: Vertical electrical sounding (VES) curves for Ekwulobia

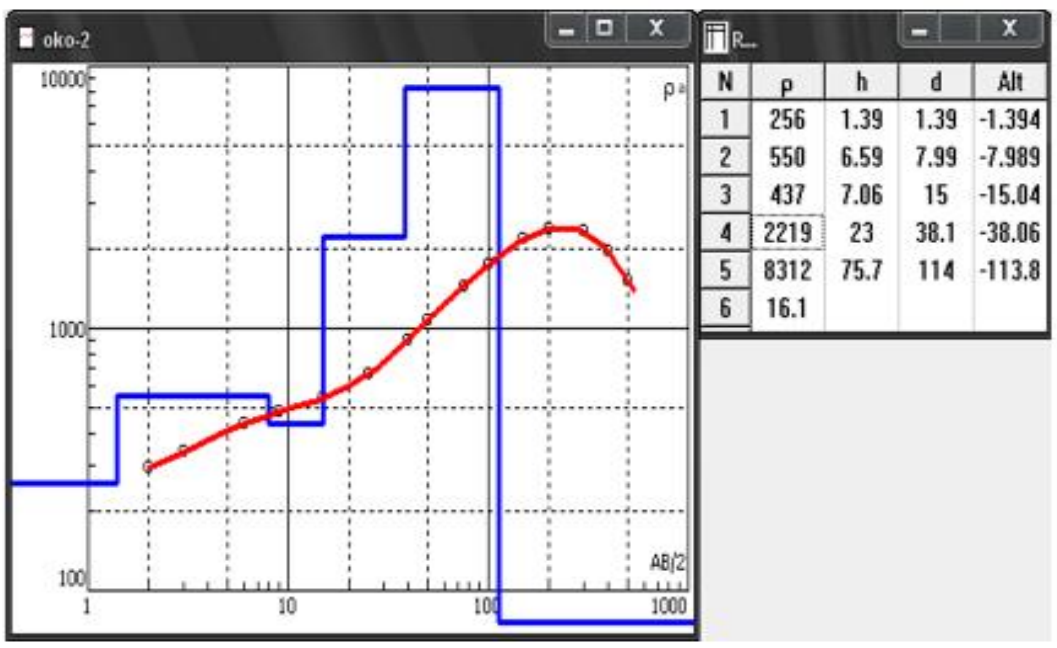

Figure 3e: Vertical electrical sounding (VES) curves for Oko 2

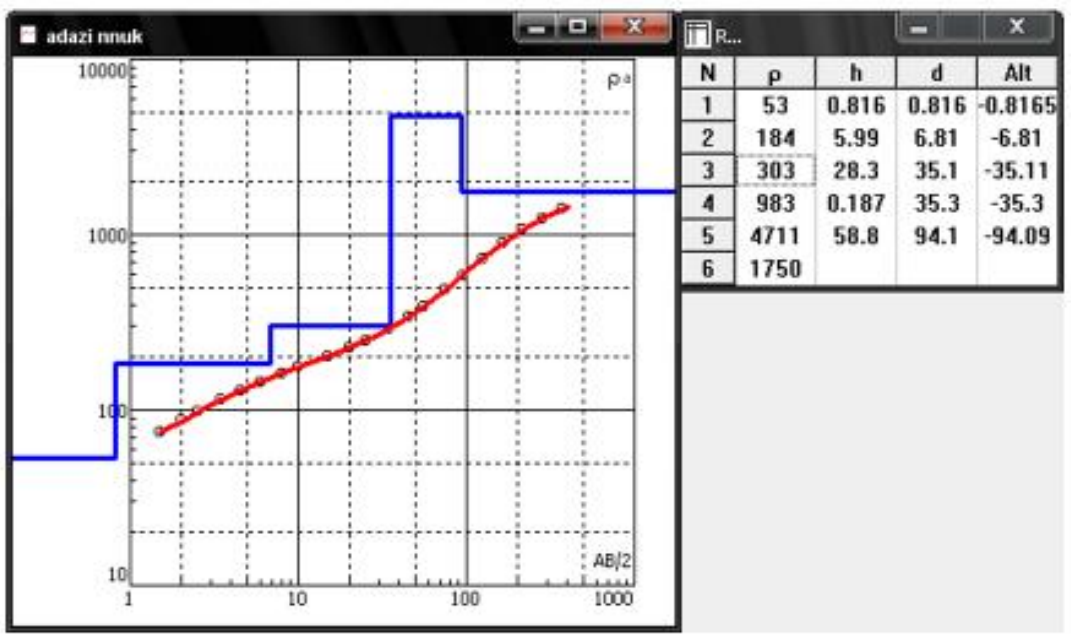

Figure 3f: Vertical electrical sounding (VES) curves for Adazi 


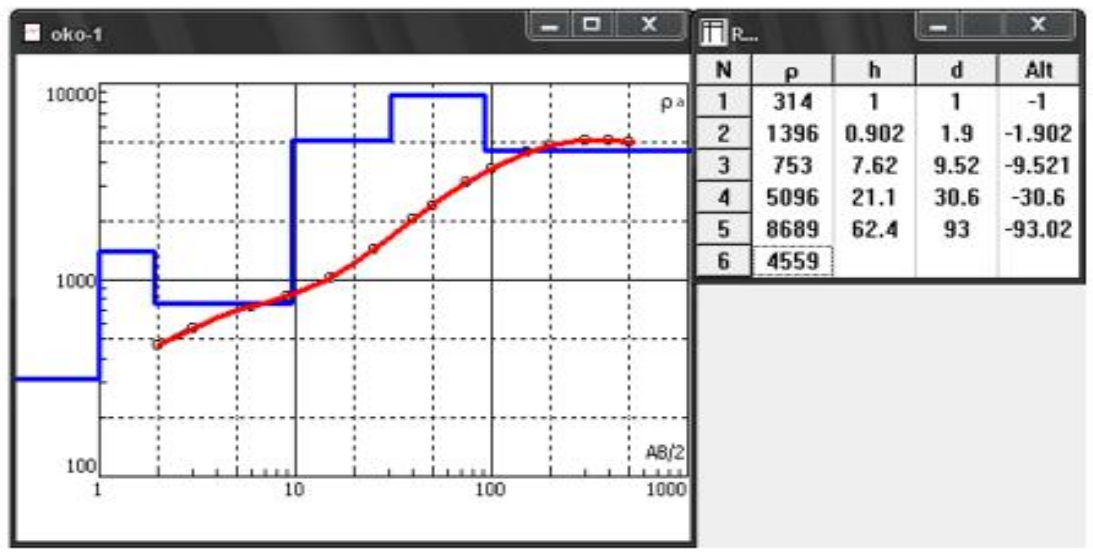

Figure 3g: Vertical electrical sounding (VES) curves for Oko 1

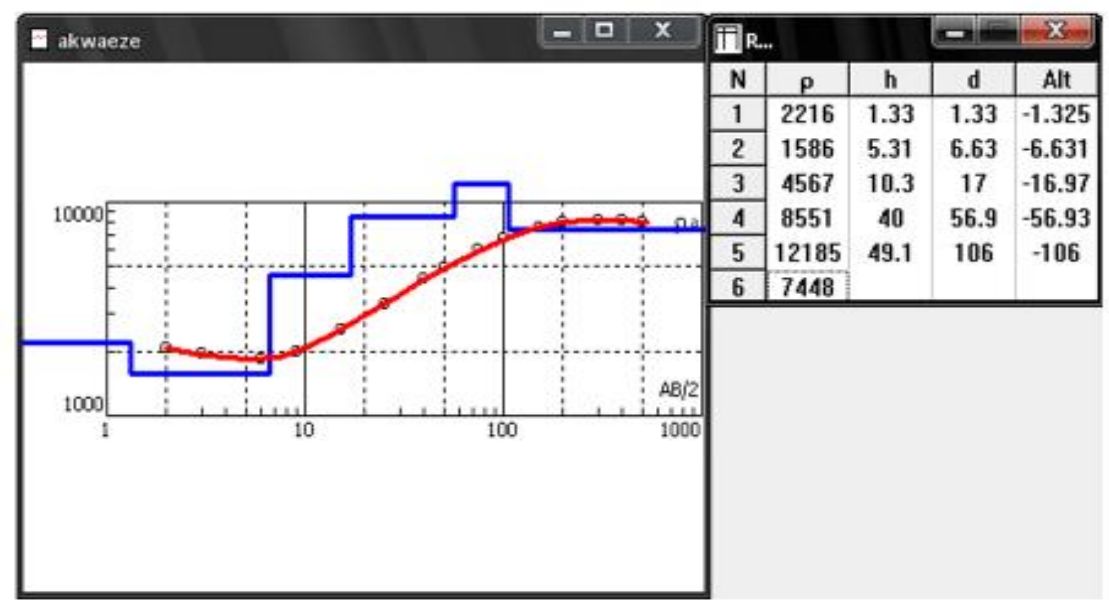

Figure 3h: Vertical electrical sounding (VES) curves for Akwaeze

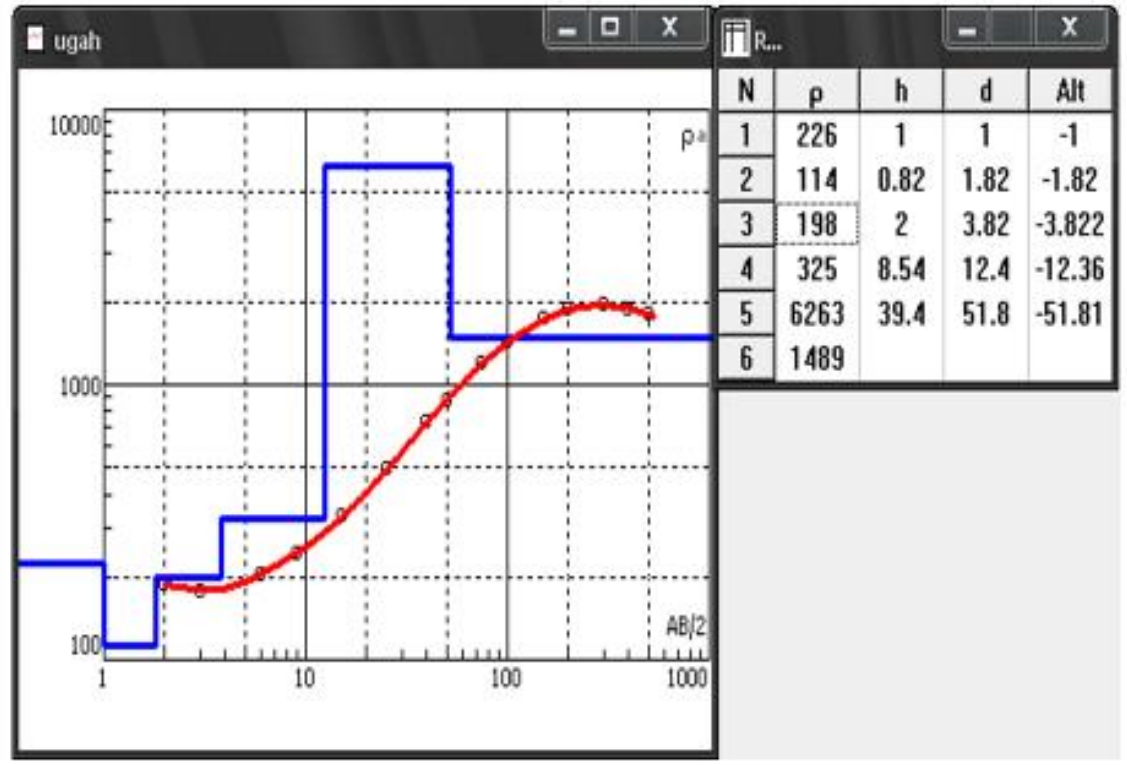

Figure 3i: Vertical electrical sounding (VES) curves for Ugah 


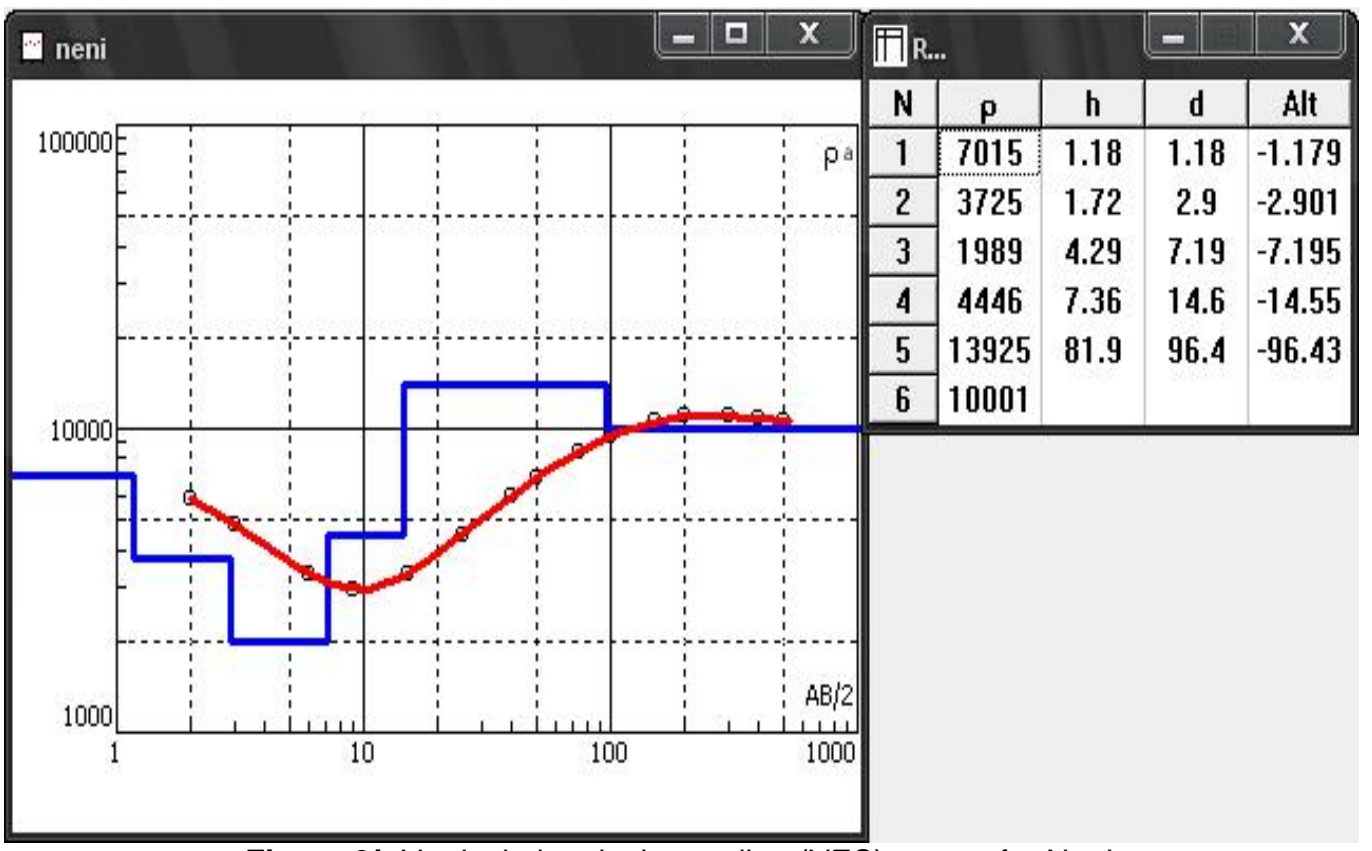

Figure 3j: Vertical electrical sounding (VES) curves for Neni

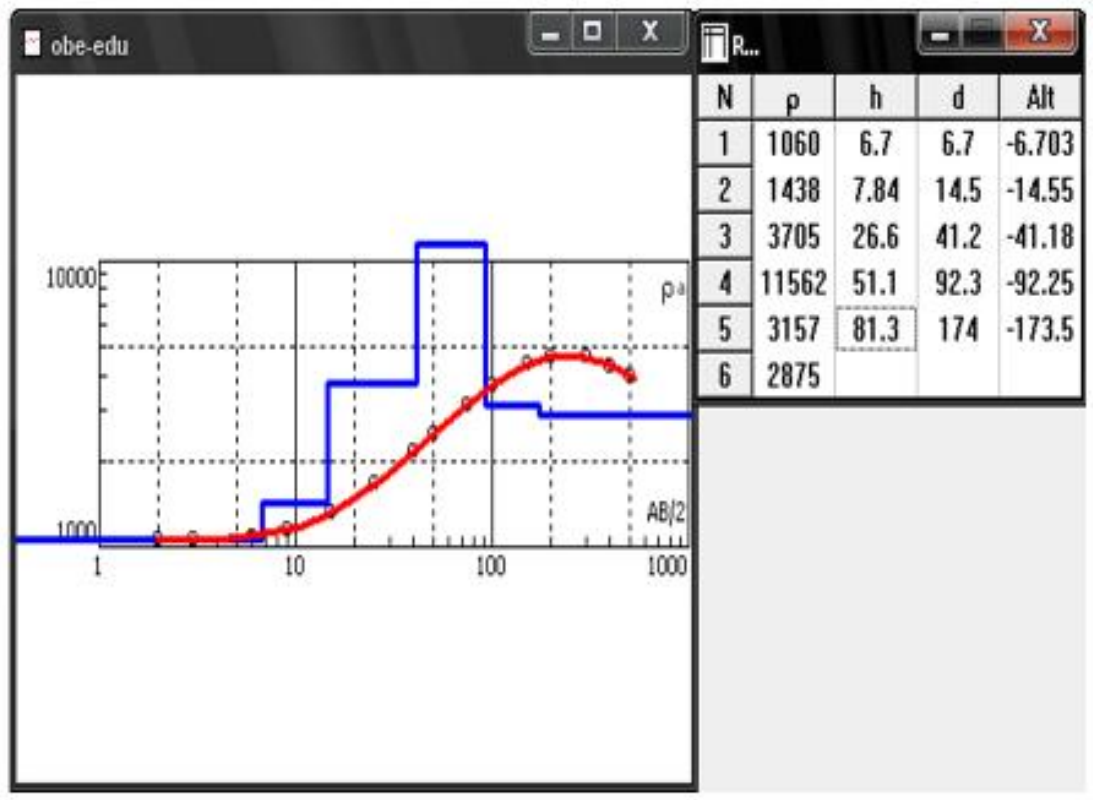

Figure 3k: Vertical electrical sounding (VES) curves for Obe-Edu 

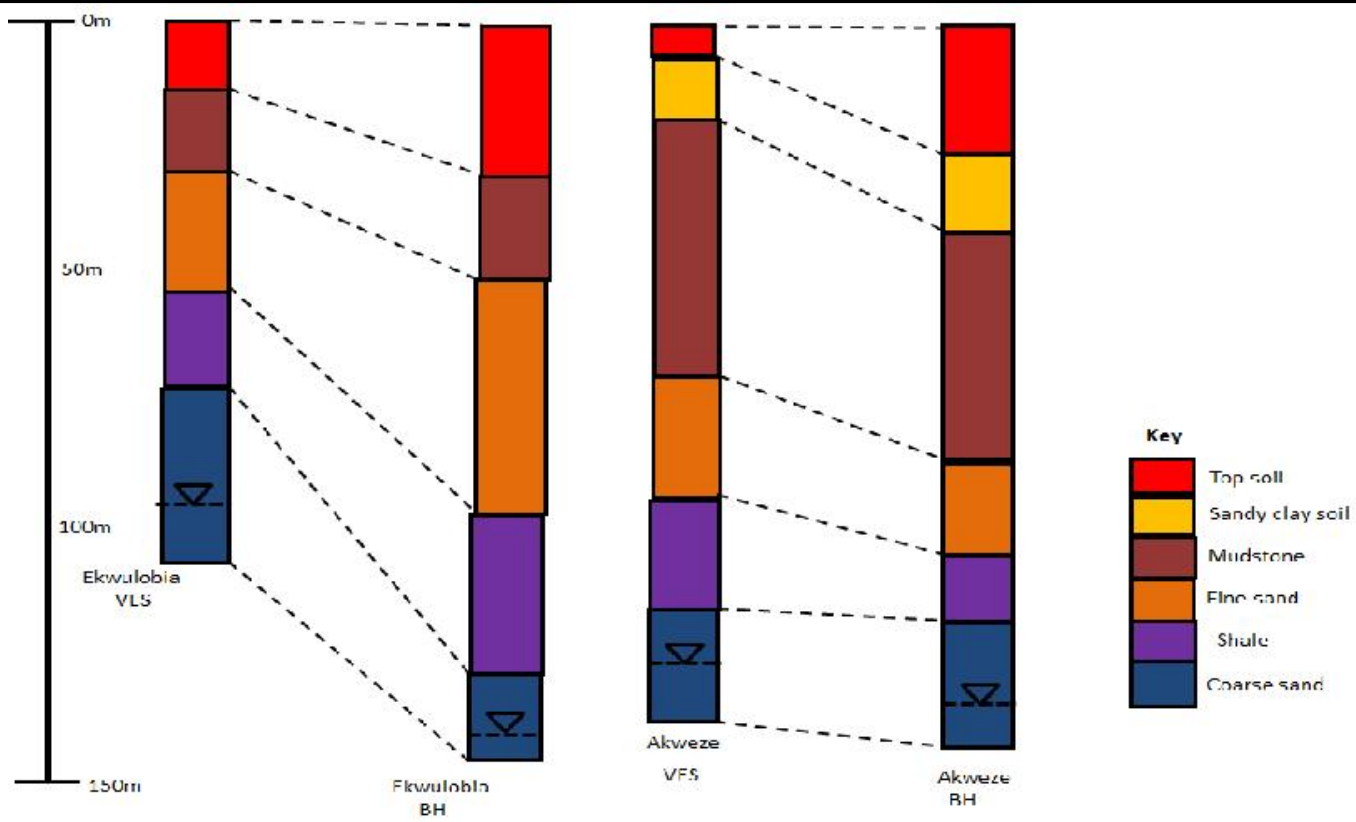

Figure 4: Comparison of the VES inferred lithologies with the borehole lithologies.

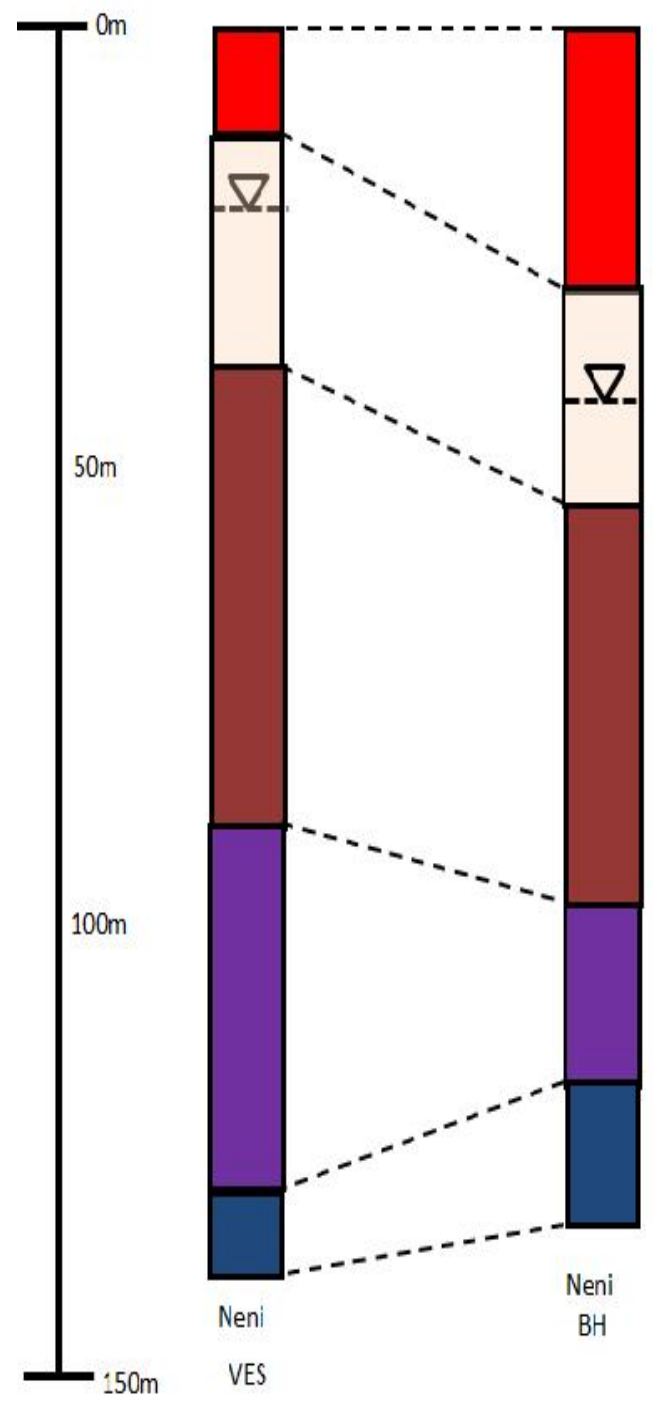

Figure 4: contd. 
highland areas, for example, a borehole located at Almasol quarter (Oko), with ground elevation of $339.6 \mathrm{~m}$ above mean sea levels (amsl) has static water level (swl) of $213.6 \mathrm{~m}$ while the lower horizons aquifers are located at the topographically low land areas. For example, a Federal Borehole located at Nanka area, about $2.5 \mathrm{~km}$ away from the Almasol Borehole, with ground elevation of $162.9 \mathrm{~m}$ amsl has swl of $38.9 \mathrm{~m}$. Further down the slope, $500 \mathrm{~m}$ distance from the Federal Borehole at Enugu-Nanka area, the aquifer is exposed by erosion at its lowest point of $126 \mathrm{~m}$ amsl, where the water table is intersected, issuing as spring in the location Figure 5. Figure 6 presents the spatial distributions of the aquifer horizon types, with the upper horizon aquifers confined to the northern section of the study area while the lower aquifer horizon is confined to the central and southern sections. Both horizons are unconfined in view of the lithologies and the static water levels measured.

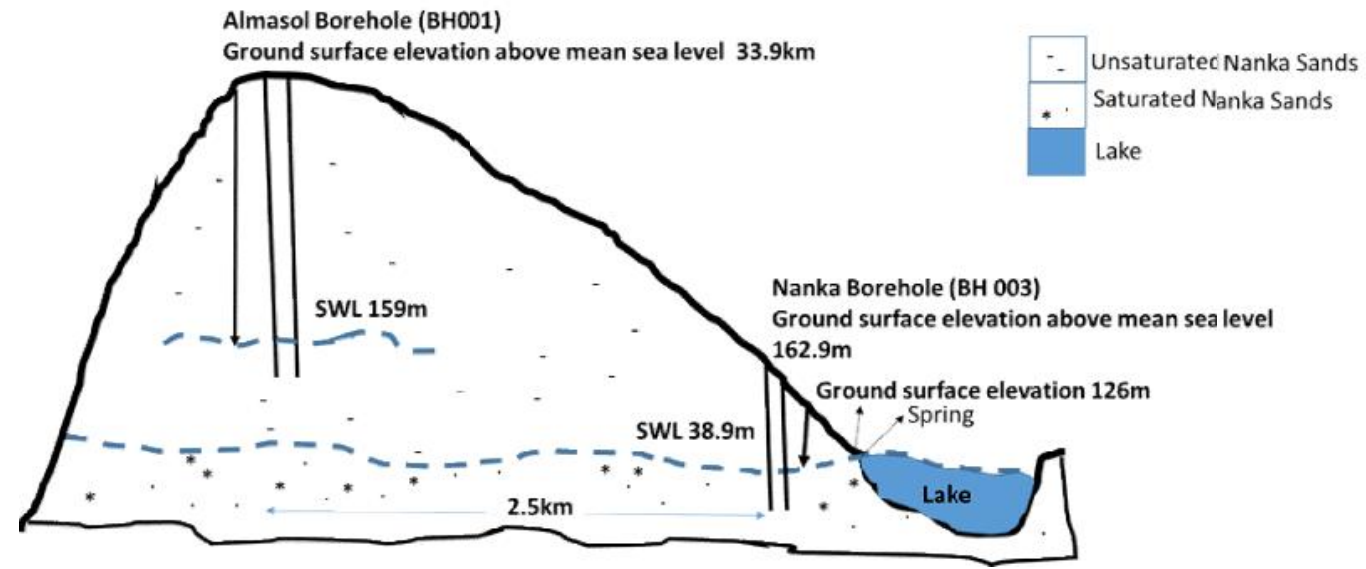

Figure 5: Sketch field diagram of the lower and upper horizon aquifers

The study area, Nanka-Oko area is a watershed ridge in the Mamu sub-basin with River Otimi taking its origin from this ridge and then flows northwards to join River Mamu and then with River Anambra in the extreme northern part of the Anambra basin. Groundwater recharge via precipitation constitutes the dominant or main contribution to groundwater in the area. Because of the high porosity and permeability of the Nanka Sands sediments, recharge rate in the area is high as there is absence of surface runoff in the area. The recharge pattern is direct and diffuse.

Groundwater potential of the area was evaluated based on transmissivity values of the aquifers. The Krasny (1993) model was employed in classifying the area into groundwater potential zones. Aquifer parameters such as hydraulic conductivity, $\mathrm{K}$ and transimissivity, $\mathrm{T}$ for some locations in the area are presented in Table 4. From the

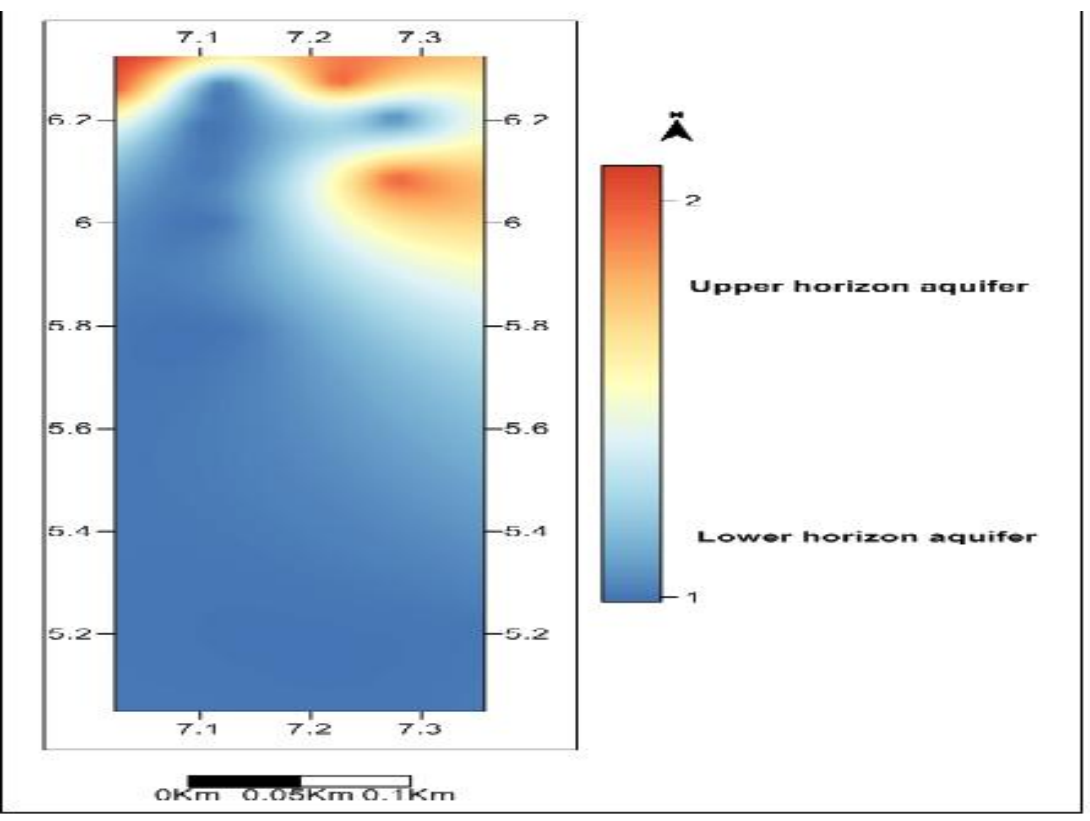

Figure 6: Spatial distribution map of the aquifer horizon types 
table, the hydraulic conductivity value is highest at Obedelu $\left(7.2 \times 10^{-2} \mathrm{~cm} / \mathrm{s}\right)$ and lowest at Uga $\left(3.1 \times 10^{-2} \mathrm{~cm} / \mathrm{s}\right)$ while transmissivity varied from 33.48 $\mathrm{m}^{2} / \mathrm{hr}$ at Uga to $77.76 \mathrm{~m}^{2} / \mathrm{hr}$ at Obeledu. Table 4 also shows a summary of the groundwater potentials of the area in relation to the aquifer horizon (lower and upper) type.

Table 4: Borehole characteristics and Aquifer parameters of some boreholes drilled within the study area

\begin{tabular}{|c|c|c|c|c|}
\hline Location & $\begin{array}{l}\text { Hydraulic } \\
\text { conductivity } \\
(\mathrm{cm} / \mathrm{s})^{*} 10^{-2}\end{array}$ & $\begin{array}{l}\text { Transmissivity } \\
\left(\mathrm{m}^{2} / \text { day }\right)\end{array}$ & $\begin{array}{l}\text { Groundwater } \\
\text { potential rating }\end{array}$ & Aquifer horizon \\
\hline Uga & 3.1 & 803.52 & High & Lower \\
\hline Ekwulobia & 3.4 & 1468.8 & Very high & Lower \\
\hline Oko & 6.3 & 1360.8 & Very high & Lower \\
\hline AdaziNnukwu & 5.2 & 1123.2 & Very high & Lower \\
\hline Neni & 6.8 & 1644.96 & Very high & Upper \\
\hline Obeleedu & 7.2 & 1866.24 & Very high & Upper \\
\hline Nanka & 4.8 & 1451.52 & Very high & Lower \\
\hline Mkpologwu & 3.8 & 820.8 & High & Lower \\
\hline
\end{tabular}

\section{Groundwater chemistry}

The results of the physiochemical and biological analysis of groundwater from the study area are presented in Table 5. From the table, $\mathrm{pH}$ ranges from 5.9 to 7.0 with a mean of 6.43 and this shows that the groundwater in the entire study area is slightly acidic to neutral. The order of magnitude of the ionic species is $\mathrm{Ca}^{2+}>\mathrm{Na}^{+}>\mathrm{HCO}_{3}^{-}>>\mathrm{Mg}^{2+}>\mathrm{Cl}^{-}>\mathrm{SO}_{4}^{2-}>\mathrm{NO}_{3}^{-}>\mathrm{Fe}^{3+}$. All the ionic species $\left(\mathrm{HCO}_{3}^{-}, \mathrm{SO}_{4}^{2-}, \mathrm{Cl}^{-}, \mathrm{NO}_{3}^{-}, \mathrm{Fe}^{2+/ 3+}\right.$, $\mathrm{Na}^{+}, \mathrm{Mg}^{2+}$ and $\mathrm{Ca}^{2+}$ ) and also $\mathrm{SiO}_{2}$ are thought to be released from weathering processes of ferromagnesian minerals, clay minerals, calcite, dolomite, anorthite and plagioclase bearing rocks, as well as from dilution processes except $\mathrm{NO}_{3}^{-}$which has an anthropogenic source (domestic wastes and leachates from plants nutrients and nitrate fertilizers) (Ayuba et al., 2017). In addition, ions in the groundwater may be affected by anthropogenic sources such as cation of nitrate fertilizer, anion of ammonium fertilizer, other soil amendments and domestic wastewater. The Box Plots of the major ions from the two 
Table 5: Summary of the results of the physiochemical and biological analyses

\begin{tabular}{|c|c|c|c|c|c|c|c|c|c|c|c|c|c|c|c|}
\hline Location & $\mathrm{pH}$ & $\mathrm{TH}$ & $\mathrm{Ca}$ & $\mathrm{Mg}$ & $\mathrm{Na}$ & $\mathrm{Fe}$ & $\mathrm{HCO}_{3}$ & $\mathrm{Cl}$ & $\mathrm{SO}_{4}$ & $\mathrm{NO}_{3}$ & $\mathrm{SiO}_{2}$ & E.coli & $\begin{array}{l}\text { Plate } \\
\text { count }\end{array}$ & Coliform & $\begin{array}{l}\text { Aquifer } \\
\text { horizon }\end{array}$ \\
\hline 1 & 6.85 & 84 & 35.25 & 6.51 & 5.94 & 0.06 & 19.00 & 8.62 & 71 & 0 & 9.02 & -ve & 5 & 0 & Upper \\
\hline 2 & 5.9 & 63.2 & 23.26 & 6.91 & 25 & 0.5 & 63 & 16.6 & 21.4 & 0.35 & 3 & -ve & 7.01 & 3.21 & Upper \\
\hline 3 & 6.4 & 68 & 20.08 & 5.34 & 25.74 & 0.2 & 65.30 & 15.6 & 8.82 & 0.49 & 0.4 & -ve & 8 & 2 & Lower \\
\hline 4 & 6.4 & 44.4 & 30.5 & 6.38 & 32.15 & 0.03 & 60.00 & 13.3 & 6.94 & 0.32 & 1.0 & -ve & 8 & 1.5 & Lower \\
\hline 5 & 6.2 & 48.23 & 25.4 & 4.7 & 21.72 & 0.03 & 45.07 & 14 & 6.24 & 0.01 & 7 & -ve & 0 & 2 & Lower \\
\hline 6 & 6.85 & 71.4 & 18.09 & 10.2 & 22.61 & 0.02 & 37.65 & 16.25 & 6.35 & 0.11 & 3 & -ve & 8 & 2 & Lower \\
\hline 7 & 6.4 & 79.6 & 14.26 & 10.16 & 3.1 & 0.65 & 15.00 & 5.62 & 62 & 0 & 12 & -ve & 10 & 0 & Undefined \\
\hline 8 & 6.2 & 55 & 19.5 & 1.8 & 23.39 & 0.2 & 50.4 & 14.18 & 18.2 & 0.65 & 4 & -ve & 12 & 4 & Upper \\
\hline 9 & 6.4 & 71.21 & 13 & 4.62 & 29.61 & 0.01 & 53.2 & 12.21 & 12.2 & 0 & 5.05 & -ve & 9 & 1.2 & Upper \\
\hline 10 & 6.3 & 89.15 & 25.05 & 3.26 & 18.35 & 0.02 & 50 & 10.64 & 6.1 & 60.2 & 6.05 & -ve & 6 & 2.01 & Lower \\
\hline 11 & 6.3 & 62 & 17.2 & 1.3 & 21.42 & 0.01 & 40.5 & 17.16 & 14.3 & 0.15 & 2 & -ve & 10 & 3 & Lower \\
\hline 12 & 6.5 & 72.5 & 30.06 & 10 & 32.4 & 0.05 & 50 & 20.6 & 18 & 0.7 & 4 & -ve & 12 & 2 & Lower \\
\hline 13 & 6.25 & 65 & 20.25 & 6.72 & 38.4 & 0.02 & 35 & 16.8 & 22.3 & 5.05 & 7 & -ve & 8 & 2 & Lower \\
\hline 14 & 6.6 & 84.17 & 22.08 & 6.24 & 26.64 & 0.3 & 55.2 & 10.5 & 6.1 & 0.36 & 6.35 & -ve & 6 & 3 & Lower \\
\hline 15 & 7 & 88.41 & 35.05 & 2.62 & 35.1 & 0.03 & 58.4 & 20.5 & 20.1 & 0.12 & 3.08 & -ve & 10 & 0.09 & Lower \\
\hline 16 & 6.35 & 95.62 & 10 & 3.25 & 24.21 & 0.01 & 50.4 & 15.7 & 4.5 & 0.23 & - & -ve & 6 & 1 & Lower \\
\hline $\begin{array}{l}\text { WHO } \\
(1993)\end{array}$ & $7-9$ & 100 & 75 & 50 & & 0.05 & & 200 & 200 & 45 & & $0 / 100$ & 100 & $3 / 100$ & \\
\hline Mean & 6.43 & 71.37 & 22.44 & 5.626 & 24.11 & 0.13 & 46.76 & 14.27 & 19.0 & 4.30 & 4.863 & & 7.81 & 1.8131 & \\
\hline Min. & 5.9 & 44.4 & 10 & 1.3 & 3.1 & 0.01 & 15 & 5.62 & 4.5 & 0.000 & 0.40 & & 0.00 & 0.00 & \\
\hline Max. & 7.0 & 95.62 & 35.25 & 10.2 & 38.4 & 0.65 & 65.3 & 20.6 & 71.0 & 60.2 & 12 & & 12 & 4.0 & \\
\hline SD & 0.28 & 14.89 & 7.477 & 2.84 & 9.377 & 0.19 & 14.43 & 4.05 & 19.6 & 14.96 & 3.11 & & 2.949 & 1.16743 & \\
\hline CV & 0.08 & 221.6 & 55.91 & 8.05 & 87.93 & 0.04 & 208.07 & 16.41 & 383 & 223.7 & 9.69 & & 8.695 & 1.363 & \\
\hline
\end{tabular}

1-Neni 1; 2- Neni 2; 3-Oko Poly; 4-Oko 2; 5-Ekwulobia1; 6-Ekwulobia 2; 7-Agulu; 8- Obeledu 1; 9- Obeledu 2; 10- Nanka 1; 11 - Nanka- 2; 12 - Mkpologwu 1; 13- Mkpologwu 2; 14-Uga 1; 15-Uga 2; 16 -Uga 3 
aquifer horizons are presented in Figure 7. $\mathrm{SO}_{4}^{2-}$ among the ions, shows the highest variability in concentrations from the two aquifer horizons. It is, however, higher in concentration in the upper horizon aquifers than in the lower horizon aquifers (see Figure 6). This low concentration of the ion in the lower horizon aquifer may have resulted from adsorption of the ion by clay-rich layers above the lower horizon aquifers.

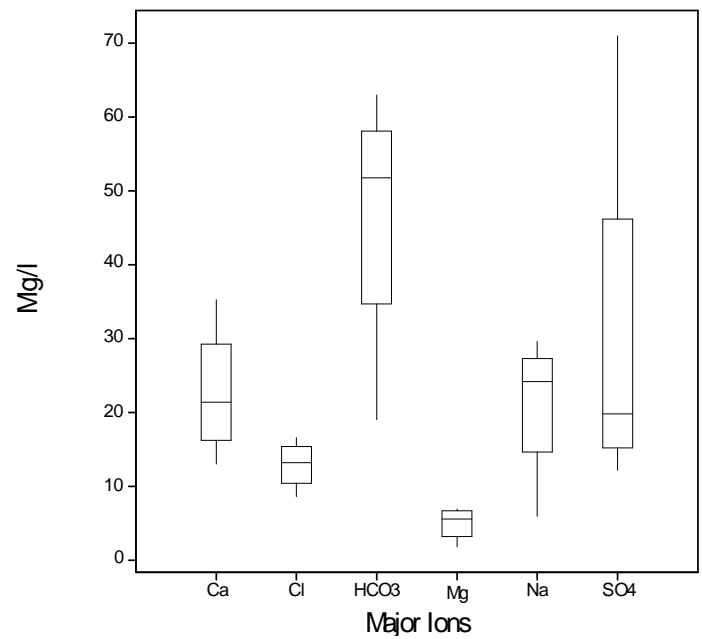

Figure 7a: Box Plot of major ions of upper horizon aquifers.

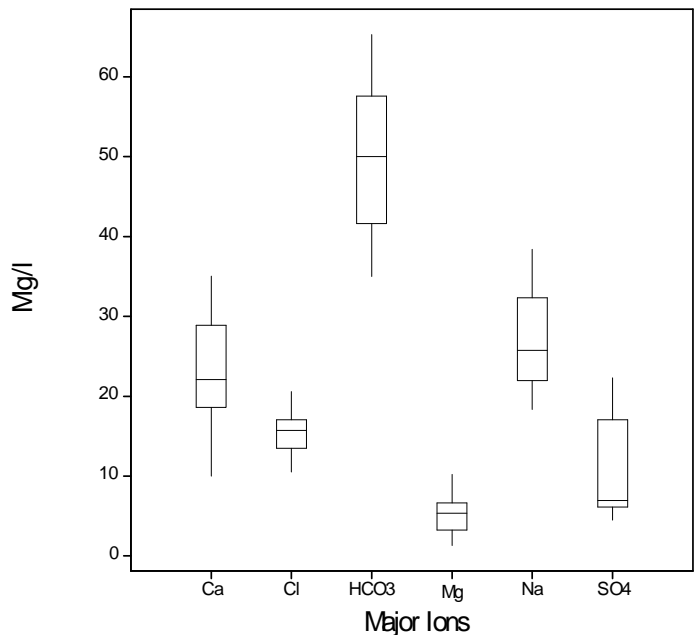

Figure 7b: Box Plot of major ions of lower horizon aquifers.

Hydrochemical facies and hydrochemical processes Piper diagram of the major ionic species $\left(\mathrm{HCO}_{3}^{-}, \mathrm{SO}_{4}^{2-}, \mathrm{Cl}^{-}, \mathrm{Na}^{+}, \mathrm{Ca}^{2+}\right.$, and $\mathrm{Mg}^{2+}$ ) of the study area (Figure 8) revealed three hydrochemical facies namely, $\mathrm{CaHCO}_{3}$ type I (25\%), Mixed $\mathrm{CaMgCl}$ type III $(62.5 \%)$ and $\mathrm{CaCl}_{2}$ type $\mathrm{V}(12.5 \%)$. From the plot, alkaline earth metals ( $\mathrm{Ca}$ and $\mathrm{Mg}$ ) exceed the alkali metals $(\mathrm{Na}$ and $\mathrm{K})$, and the strong acids $\left(\mathrm{Cl}\right.$ and $\left.\mathrm{SO}_{4}\right)$ exceed the weak acid $\left(\mathrm{HCO}_{3}\right)$. The type I facies (samples locations 3, 4, 10, and 14 - lower horizon aquifers) denotes facies of recharge zone areas which can be described as water of primary hardness. Type III (sample locations 2, 8, and 9-upper horizon aquifers; and sample locations 5, 6, 11, 12, 13, 15 and 16-lower horizon aquifers) denotes mixed water type as no specific cation-anion pair exceeds $50 \%$ of the total dissolved constituent load. Waters of this facies type could result from multiple minerals dissolution or mixing of two chemically distinct groundwater bodies (Fetter, 2001). Type $V$ (sample locations 1-upper horizon aquifer and 7-undefined aquifer) which facies is formed when combined concentrations of chloride and calcium exceed 50 percent of total $\mathrm{meq} / \mathrm{L}$ is described as water of secondary hardness. $\mathrm{NaCl}$ type II, mixed $\mathrm{CaNaHCO}_{3}$ type IV and $\mathrm{NaHCO}_{3}$ type VI were not observed in the area. The implications of the facies types identified in the study area vis-à-vis their locations with respect to aquifers (lower horizon and upper horizon) is that hydrochemical facies is not a function of aquifer depth or 
horizon type but a function of variations in lithologies, solution kinetics and flow pattern of the aquifers (Fetter (2001).

The distributions of the geochemical facies or water type also tell of the geochemical flow path.
According to Poehls and Smith (2009), geochemical flow paths begin at the calcium bicarbonate water type $\left(\mathrm{CaHCO}_{3}\right.$, type I) through sodium bicarbonate mixed calcium magnesium chloride water type $(\mathrm{CaMgCl}$, type III),to chloride water

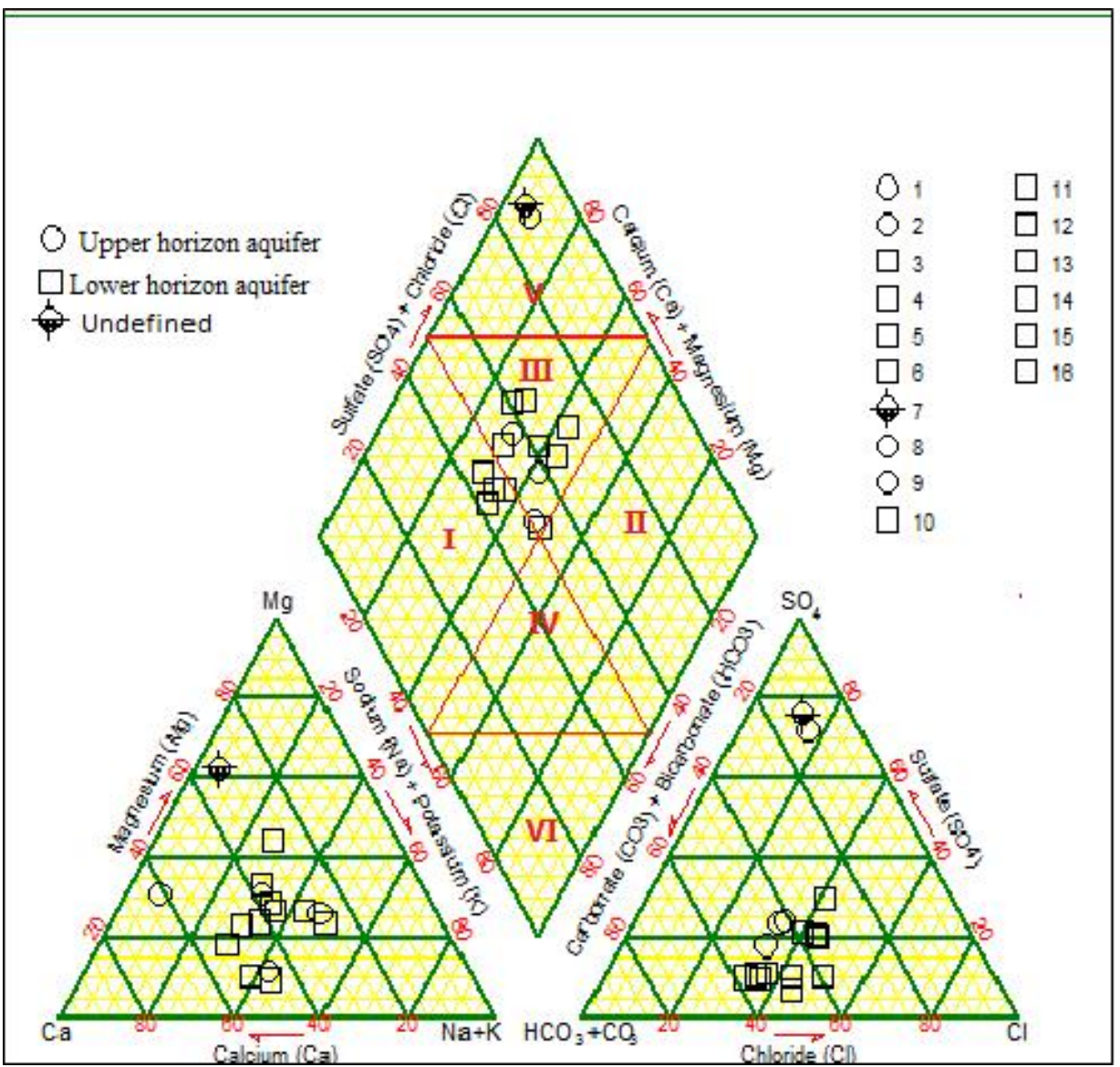

Figure 8: Piper Diagram of the major ionic facies in the study area.

type ( $\mathrm{CaCl}$, type $\mathrm{V})$. The geochemical flow path model (Figure 9a) revealed the flow paths of groundwater in the area. The estimated hydraulic head data from boreholes in the area was also used in constructing a hydraulic head model in order to decipher the groundwater flow directions (Figure 9b). The hydraulic head model revealed a similar groundwater flow path as in the geochemical facies flow path model (see Figure 9).
The predominant hydrochemical processes controlling the hydrochemical characteristics of groundwater in the study area was deciphered using the Durov plot. The plot (Figure 10) shows that the main hydrochemical process controlling the groundwater chemistry is dilution and mixing. Dilution means rendering of a concentrated chemical weaker by addition of water or another less concentrated liquid 


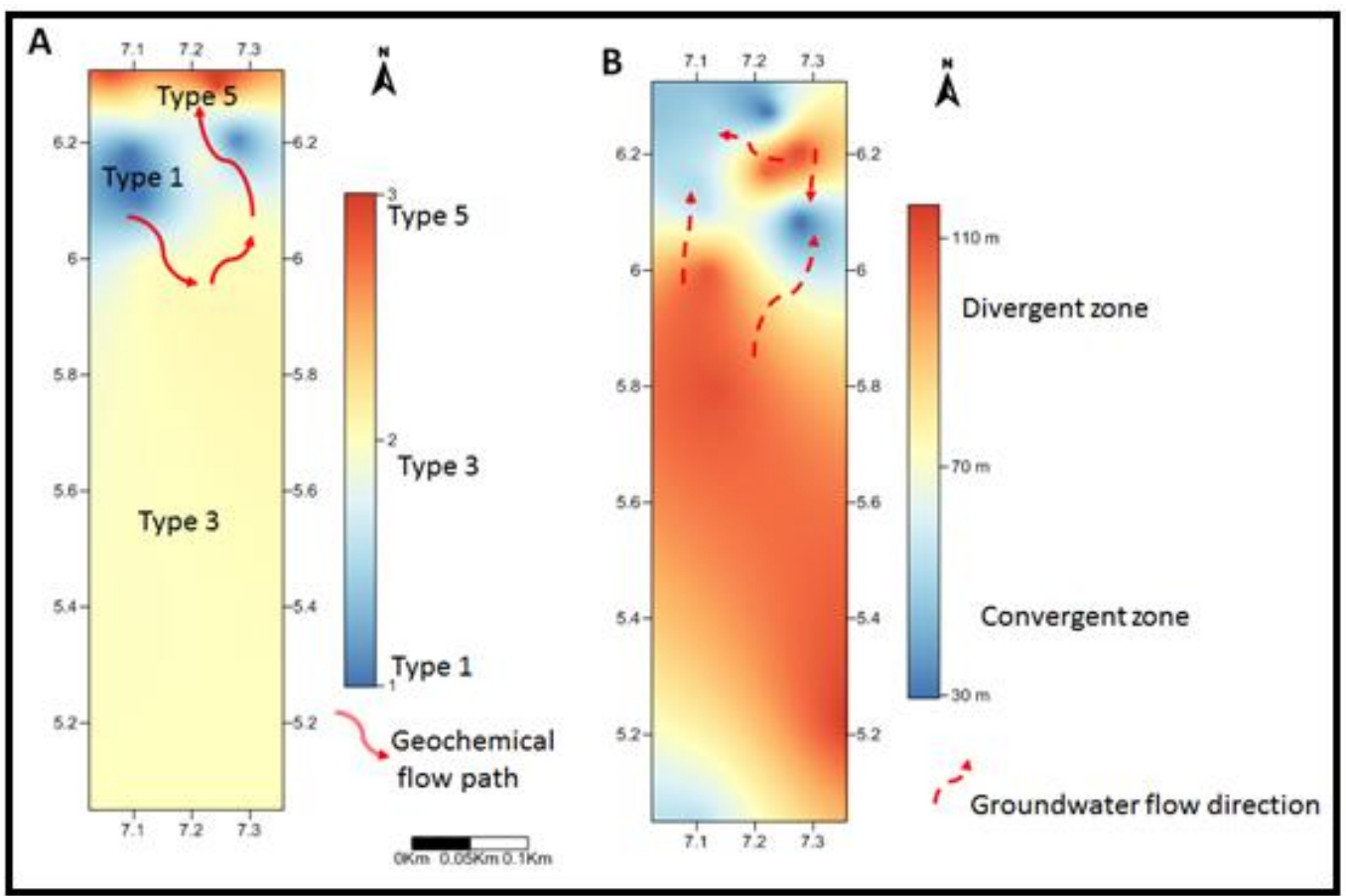

Figure 9: Geochemical and hydraulic head models

Durov Diagram

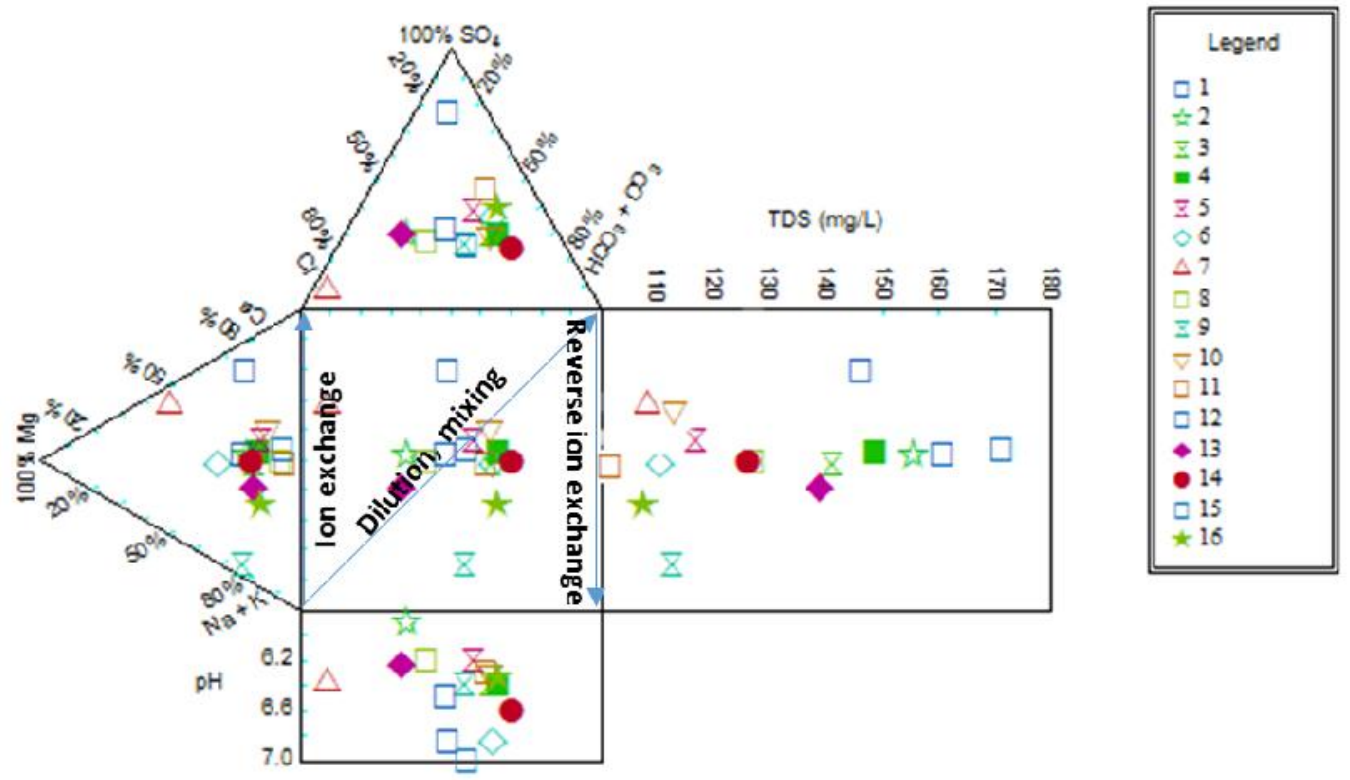

Figure 10: Durov diagram of the hydro-geochemical processes in study area

(Okogbue and Ukpai, 2013). The original chemical constituents of groundwater primarily comparing calcium, magnesium, carbonate released from weathering and leaching from rock matrix and or soil system are being altered/diluted via infiltrating precipitation. This observation is supported by the hydrochemical facies characteristics described above. Most of the groundwater within the "dilution field" of the Durov diagram also belong to the "mixed water field" of the Piper diagram. Only groundwater samples from location 7 belongs to the "ion exchange field" of the Durov diagram and incidentally, only this groundwater sample belongs to the $\mathrm{CaCl}_{2}$ facies that resulted from ion exchange processes.

\section{Drinking water qualities}

The drinking water quality evaluation was done by comparing the concentrations of the ions and other measured parameters with the World Health Organization (WHO, 1993) guidelines recommended for 
drinking water. All physiochemical parameters measured, except $\mathrm{NO}_{3}^{-}$were found to be below the desirable limit guideline values at all the locations. $\mathrm{NO}_{3}^{-}$exceeded the limit at location 10 (Table 5). The elevated concentration of $\mathrm{NO}_{3}^{-}$at this location is assumed to come from domestic wastes. Groundwater from this well (location 10) should be used only after it has been treated by ion exchange processes, reverse osmosis, or distillation.

Groundwater classifications based on TDS (Davies and Dewiest, 1966 and Freeze and Cherry, 1979) place the groundwater of the area at "water desirable for drinking" class and "freshwater type" class respectively. Sawyer and McCarty (1967)'s classification of groundwater based on total hardness shows that 37.5 $\%$ groundwater samples (from locations 1, 7, 10, 14, 15 and 16) falls in the "moderately hard" class ( $\mathrm{TH}$ as $\mathrm{CaCO}_{3} 75 \mathrm{mg} / \mathrm{l}-150 \mathrm{mg} / \mathrm{l}$ ) while $62.5 \%$ samples (from locations 2, 3, 4, 5, 6, 8, 9, 11, 12 and 13) falls in the "soft" class ( $\mathrm{TH}$ as $\mathrm{CaCO}_{3}=75 \mathrm{mg} / \mathrm{L}-150 \mathrm{mg} / \mathrm{L}$ ). Hardness in water causes scale in water heaters, boilers, pipes and turbines; it also consumes excessive quantities of soap during washing activities (Onwuka et al., 2013). Primary hardness in water, as observed in Type I facies (groundwater samples from locations 3, 4, 10 and 14 (Figure 7) can be removed by distillation (Freeze and Cherry, 1979) while secondary hardness, as observed in Type $\mathrm{V}$ facies (groundwater samples from locations 1 and 7 (Figure 8) can be removed through ion exchange processes and addition of hydrated lime followed by sedimentation and then filtration.

Biological parameters of E.coli are below the stipulated standard of $0 / 100 \mathrm{ml}$ per sample in all the groundwater samples, just as Heterotrophic plate count measured in all the samples are below the stipulated standard of 100 counts. Total coliforms in samples 2,8 , 11 and 14 are, however, above the guideline value of $1 / 100 \mathrm{ml}$ per sample (Table 5).

\section{Irrigation water qualities}

The mineral constituents of groundwater determine its suitability for irrigation purposes. Dissolved salts in groundwater used for irrigation affect both plant growth and soil structure; they also affect other properties such as permeability, aeration and texture. High salt content in irrigation water causes increased osmotic pressure in soil solution which in turn retards minerals and water uptake by plants. Irrigation quality of the groundwater of the study area was evaluated based on the following quality indices: electrical conductivity (EC), sodium adsorption ratio (SAR), sodium percentage ( $\mathrm{Na} \%)$, residual sodium carbonate (RSC), magnesium hazard $(\mathrm{MH})$, permeability index $(\mathrm{PI})$ and Kelly ratio. These quality parameters are presented in Table 6 which when compared with various specifications (salinity, sodium percentage, United States salinity classification of groundwater for irrigation (USSL), sodium residual carbonate

Table 6: Irrigation water quality indices

\begin{tabular}{llllllll}
\hline & $\begin{array}{l}\text { EC } \\
(\mu S / \mathrm{cm})\end{array}$ & SAR & Na\% & $\begin{array}{l}\text { RSC } \\
(\mathrm{meq} / \mathrm{l})\end{array}$ & $\mathrm{MH}$ & $\begin{array}{l}\mathrm{PI} \\
(\%)\end{array}$ & $\begin{array}{l}\text { Kelly } \\
\text { ratio }\end{array}$ \\
\hline 1 & 175 & 0.241246 & 10.12204 & -1.98295 & 23.33474 & 31.98245 & 0.11262 \\
2 & 125 & 1.169641 & 38.6124 & -0.69638 & 32.86837 & 74.69164 & 0.628994 \\
3 & 40 & 1.319039 & 43.72348 & -0.37089 & 30.47292 & 84.12178 & 0.77694 \\
4 & 65 & 1.382498 & 40.59383 & -1.06324 & 25.6367 & 69.37808 & 0.683327 \\
5 & 70 & 1.038958 & 36.3559 & -0.91529 & 23.36946 & 69.42779 & 0.571238 \\
6 & 50 & 1.053994 & 36.09205 & -1.12446 & 48.16705 & 64.91866 & 0.56475 \\
7 & 100 & 0.153321 & 8.017325 & -1.30128 & 54.00691 & 37.49639 & 0.087161 \\
8 & 30 & 1.358989 & 47.5774 & -0.29503 & 13.20439 & 90.07711 & 0.907574 \\
9 & 65 & 1.796011 & 55.59822 & -0.1567 & 36.93669 & 95.90504 & 1.252162 \\
10 & 95 & 0.9162 & 34.46088 & -0.6986 & 17.66042 & 73.54276 & 0.525806 \\
11 & 40 & 1.341272 & 49.11907 & -0.3014 & 11.07676 & 92.06859 & 0.965373 \\
12 & 45 & 1.30792 & 37.76736 & -1.50289 & 35.41173 & 62.02546 & 0.606874 \\
13 & 40 & 1.889462 & 51.65875 & -0.98948 & 35.35557 & 75.08198 & 1.068627 \\
14 & 60 & 1.289604 & 41.77792 & -0.71024 & 31.7763 & 76.0691 & 0.717561 \\
15 & 70 & 1.540598 & 43.73282 & -1.00729 & 10.96833 & 71.75533 & 0.777235 \\
16 & 65 & 1.701396 & 57.88317 & 0.059776 & 34.8802 & 107.8375 & 1.374347 \\
Max & 175 & 1.889462 & 57.88317 & 0.059776 & 54.00691 & 107.8375 & 1.374347 \\
Min & 30 & 0.153321 & 8.017325 & -1.98295 & 10.96833 & 31.98245 & 0.087161 \\
Mean & 70.94 & 1.19683 & 38.83295 & -0.83219 & 29.4501 & 73.1222 & 0.726783 \\
\hline
\end{tabular}

Min-minimum; Max-maximum;

(RSC), permeability index (PI)) shows that the groundwater from the entire study area can be said to range from "permissible" to "excellent", with respect to suitability for irrigation purposes. 


\section{CONCLUSIONS}

The groundwater potentials as well as the hydrochemical characteristics and quality of the aquifers of Nanka-Oko area and its environs have been evaluated through an integrated technique embodying geological, geophysical and geochemical investigations. The electrical resistivity, mainly vertical electrical sounding (VES) conducted at different stations revealed that the area is principally a five-geoelectric-subsurfacelayer. The VES results in combination with available lithologic logs from drilled boreholes showed that the area is characterized by two aquifer depth horizon types (upper and lower horizons). Based on the estimated hydraulic conductivity determined from Empirical formula of grain size distribution, (Uma et al, 2001), two groundwater potential zones (very high and high) were observed. The zones were found to be independent of the aquifer horizon type.

Piper diagram on the other hand defined three hydrochemical facies namely, $\mathrm{CaHCO}_{3}$, mixed $\mathrm{CaMgCl}$, and $\mathrm{CaCl}_{2}$ water types. The principal hydrochemical process shaping the groundwater chemistry is dilution. There was no observed marked difference in the concentrations of the dissolved ions from the two aquifers (lower horizon and upper horizon) except that $\mathrm{SO}_{4}$ has a higher concentration in the upper horizon aquifers than in the lower horizon aquifers. The lower concentration of the ion in the lower horizon aquifers could be explained in terms of adsorption of the ion by the overlying layers which are absent in the upper horizon aquifers. Groundwater of the area does not meet the stipulated requirements for drinking purposes. However, the groundwater is suitable for irrigation purposes.

\section{REFERENCES}

Abiola, O., Enikanselu, P. A and Oladapo, M. I., 2009. Groundwater potential and aquifer protective capacity of overburden units in Ado-Ekiti, Southwestern Nigeria. International Journal of Physical Sciences, 4: 120-132.

Adeniji, A. E., Obiora, D. N., Omonona, O. V and Ayuba, R., 2013. Geoelectric evaluation of groundwater potentials of Bwari basement area, central Nigeria. International Journal of Physical Sciences, 8: 1350-1361.

Atakpo, E. A and Ayolabi, E. A., 2009. Elevation of aquifer vulnerability and protective capacity in some oil producing communities of western Niger delta, Environmentalist. 29: 310-317.

Ayuba, R., Tijani, M. N and Omonona, O. V., 2017. Hydrochemical characteristics and quality assessment of groundwater from shallow wells in Gboloko area, central Nigeria. Global Journal of Geological Sciences, 15,(in press).

Ayuba, R., Omonona, O. V and Onwuka, O. S., 2013. Assessment of groundwater quality of Lokoja Basement area. Journal of Geological Society of India, 82:413-420.
Bhattacharya, P. K and Patra, H. P., 1968. Direct current geoelectric sounding principles and interpretation. Elssterdam, Netherlands. 1:1135.

Braga, A. O., Filho, W. M and Dourado, J. C., 2006. Resistivity (DC) method applied to aquifer protection studies. Revista Brasileira Geofisica, Brazil. 24: 513-581.

Brindha, K and Elango, L., 2011. Hydrochemical characteristics of groundwater for domestic and irrigation purposes in Madhuranthakan, Tamil Nadu. India Earth Sci. Res. 15(2): 101-108.

Chukwurah, S., 1992. Basic Technology of Borehole. Macmillan, Nigeria, 12p.

Davies, S. N and Dewiest, R. J. M., 1966. Hydrogeology. Wiley, New York, 463p

Dorbrin, M. B., 1976. Introduction to geophysical prospecting. New York Hill Book Company, United Kingdom. 350p.

Egboka, B. C. E. and Okpoko, E. I. 1984. Gully erosion in the Agulu-Nanka Region of Anambra State, Nigeria: Challenges in African Hydrology and Water Resources (Proceedings of the Harare Symposium, July 1984). International Association of Hydrogeologists Society Publication. No. 144.

Ehirim, C. $\mathrm{N}$ and Ofor, W., 2011. Assessing aquifer vulnerability to contaminants near solid waste landfill sites in a coastal environment, Port Harcourt Nigeria. Trends in Applied Sciences research, 6 (2): 165-173.

EPA., 2005. Standard methods for the examination of water and wastewater 21st Edition EPA/600/R94, 173p.

Fetter, C. W., 2001. Applied Hydrogeology. PrenticeHall, New Jersey, 598p

Flores-Marquez E. L., 2001. Geophysical characterization of the Etla Valley aquifer Oaxaca, Mexico. Geofisica International. 40: 245-262.

Freeze, R. A and Cherry, J. A., 1979. Groundwater. Prentice-Hall Inc., Eagle Wood Cliffs, New Jersey, 491p.

Izuchukwu, I. B., 2010. Statistical Year Book. Economic Planning and Budget, Awka, Anambra State, 65 $\mathrm{pp}$.

Jakosky, J. J.,1950. Exploration Geophysics Second Edition. Trija Publications Company, Los Angeles United States America. 1-786.

Krasny, J. 1993. Classification of transmissivity 
magnitude and variation. Groundwater 31(2): 230-236.

Murat, R. C., 1970. Stratigraphy and Palaeogeography of the Cretaceous and Lower Tertiary in Southern Nigeria. PhD Thesis University of lbadan, Ibadan. 1- 268.

Nfor, B. N., Olobaniyi, S. B and Ogala, J. E., 2007. Extent and distribution of groundwater resources in parts of Anambra State, southeastern, Nigeria. Journal of Applied Science Management, 11, 215-221.

Offodile, M. E., 1975. A review of the Cretaceous of the Benue Valley. In Geology of Nigeria (C.A Kogbeed.), Elizabethan Publishing Company Lagos, Nigeria, 319-330.

Offodile, M. E., 2002. An Approach to Groundwater Study and Development in Nigeria $2^{\text {nd }}$ Edition. Mecon Publishing, Jos, Nigeria. 240 pp.

Ofomah, J. C and Ezeigbo, H. I., 1997. Hydrogeological evaluation of the Anambra River Basin, Southeastern Nigeria. Water Resources, 8: 1826.

Okagbue, C. O and Ezechi, J. I., 1988. Geotechnical characteristics of soils susceptible to severe gulling in eastern Nigeria. Bulletin of International Association of Engineering Geology, 38: 111-119.

Okengwo, O. N., Okeke, O. C., Okereke, C. N and Paschal, A. C., 2015. Geological and geotechnical studies of gully erosion at Ekwulobia, Oko and Nanka towns, Southeastern Nigeria, EJGE 20: 113-122.

Okogbue, C. O., Omonona, O. V and Aghamelu, O. P., 2012. Qualitative assessment of groundwater from Egbe-Mopa basement complex area, northcentral Nigeria. Environmental Earth Sciences. 67:1069-1083.

Okogbue, C. O and Omonona, O. V., 2013. Groundwater potential of Egbe-Mopa basement area, central Nigeria. Hydrological Sciences Journal 58: 1-15.

Okogbue, C. O and Ukpai, S. N., 2013. Geochemical evaluation of groundwater quality in Abakaliki area southeastern Nigeria. Jordan Journal of Earth and Environmental Sciences. 5: 1-8.

Okoro, E. I., Egboka, B. C. E., Anike, O. L and Enekwechi, E. K., 2010. Evaluation of groundwater potentials in parts of the escarpment areas of southeastern, Nigeria. International Journal of Geomatics and Geosciences, 1 (3): 544-551.
Omonona, O. V., Onwuka, O. S and Okogbue, C. O., 2013. Characterization of groundwater quality in three settlement areas of Enugu metropolis, southeastern Nigeria, using multivariate analysis. Environmental Monitoring Assessment. 186: 651-644.

Onwuka, O. S., Omonona, O. V and Anika, O. C., 2013. Hydrochemical characteristics and quality assessment of regolith aquifers in Enugu metropolis, southeastern Nigeria. Environmental Earth Sciences 70: 1135-1141.

Oyedele, K. F., Ogagarue, D. O. and Esse, O., 2011. Groundwater potential evaluation using surface geophysics at Oru-Imope, Southwestern Nigeria European. Journal of Scientific Research, 63: 515-522.

Poehls, D. J. and Smith, G. J. 2009. Encyclopedic Dictionary of Hydrogeology, Academic Press, Amsterdam. 1-517.

Sawyer, C. N and McCarty, P. L., 1967. Chemistry for Sanitary Engineers (2nd edition). McGraw-Hill, New York. 1-758p.

Uma, K. O., Egboka, B. C. E and Onuoha, K. M. 1989. New statistical grain-size method for evaluating the hydraulic conductivity of sandy aquifers. Journal of Hydrology, 108: 343-366.

Vasanthavigar, M., Srinivasamoorthy, K., Vijayaragavan, K., Rajiv-Ganthi, R., Chidambaram, S., Anandhan, P., Manivannan, R. and Vasudevan, S. 2010. Application of water quality index for groundwater quality assessment: Thirumanimuttar sub-basin, Tamil Nadu, India. Environmental Monitoring Assessment. doi: 10.1007/s10661-009-1302-1

Zohdy, A. A. R., Eaton, G. P and Mabey, D. R., 1974. Application of Surface Geophysics to Groundwater Investigations: Techniques of Water Resources Investigation of the United Geophysical Survey Book. United States Government Printing Office, Washington D1: 42-55. 
